\title{
PLEITO POR UNA ESCRIBANÍA PÚBLICA DEL NÚMERO EN CÁDIZ (1526): CRISTÓBAL DÍAZ CONTRA DIEGO RAMÍREZ DE LA RÚA
}

\author{
MARÍA DOLORES Rojas VACA ${ }^{1}$ \\ UNIVERSIDAD DE CÁDIZ
}

RESUMEN: La posesión de una escribanía pública del número de Cádiz enfrentaba, en 1526 ante el Consejo Real de Castilla, al notario gaditano Diego Ramírez de la Rúa y al escribano de los reinos Cristóbal Díaz, hermano de los notarios conversos, ya ejercientes, Diego González y Alonso de Medina. El desarrollo de este litigio posibilita, desde la práctica y su cotejo con la legislación, un acercamiento al notariado público de Cádiz a comienzos del siglo XVI, basado en aspectos institucionales tales como requisitos personales, morales y de aptitud exigidos tanto al aspirante como al notario ejerciente, así como a las vías oficiales de acceso y a las formas privadas de transmisión de los oficios. Igualmente ofrece una visión de la sociedad gaditana en la que los notarios conformaron un grupo destacado.

PALABRAS CLAVE: Diplomática notarial; notariado público; judeoconverso; pleito; Cádiz (Castilla); siglo XVI.

\section{THE LAWSUIT OVER A PUBLIC NOTARY IN CÁDIZ (1526): CRISTÓBAL DÍAZ AGAINST DIEGO RAMÍREZ DE LA RÚA}

\begin{abstract}
The possession of a notary of Cádiz number faced, in 1526 before the Royal Council of Castile, the Cadiz notary Diego Ramírez de la Rúa and the royal notary Cristóbal Díaz, brother of the notary converts, already exercising in the locality, Diego González and Alonso de Medina. The development of this litigation allows, from practice and its comparison with the legislation, an approach to the public notary of Cádiz at the beginning of the 16th century, based on institutional aspects such as personal, moral and aptitude requirements demanded from both the applicant and the notary practicing, as well as the official access roads and private forms of transmission of the trades. It also offers a vision of the Cádiz society in which the notaries formed a prominent group.
\end{abstract}

KEYWORDS: Notarial diplomacy; notarial institution; jewish convert; litigation; Cádiz (Castile); 16th century.

\footnotetext{
${ }^{1}$ Este trabajo ha sido financiado con cargo al Proyecto de Investigación de I+D del Ministerio de Ciencia, Innovación y Universidades PGC2018-093495-B-I00, titulado Notariado y construccion social de la realidad. Hacia una codificacion del documento notarial (siglos XII-XVII).
} 
En 1526 la posesión de una escribanía pública del número de Cádiz ${ }^{2}$ enfrentaba al escribano del número gaditano Diego Ramírez de la Rúa y al escribano de los reinos Cristóbal Díaz, hermano de los notarios conversos, ya ejercientes en la localidad, Diego González y Alonso de Medina ${ }^{3}$.

El propósito de este artículo es ampliar, con los datos aportados por este nuevo proceso, la información existente acerca del notariado público gaditano de comienzos del Quinientos ${ }^{4}$ a sabiendas de que constituye un espejo en el cual queda reflejada, en sus líneas generales, la imagen del notariado de Castilla del momento. En ausencia de otras fuentes ${ }^{5}$, el trabajo se construye sobre la base del material documental representado por la documentación emitida y, en especial, recibida por los Consejos asesores de la Corona, depositada en la actualidad en el Archivo General de Simancas y organizada en las secciones Consejo Real de Castilla y Registro General del Sello.

\section{El pleito Díaz-Ramírez de la Rúa (1526)}

El pleito se conserva fraccionado en torno a tres unidades documentales de contenido desigual. La más extensa consta de siete cuadernos donde se asientan los documentos presentados por las partes ante el Consejo Real al objeto de dar a conocer y fundamentar sus pretensiones. Consisten en memoriales, peticiones y escritos alegatorios, a los que se suman las probanzas de interrogaciones de los testigos que deponen por los litigantes. Dos sentencias fallando la recepción a prueba conforman el único vestigio de los trámites inherentes a la dinámica del proceso $^{6}$. Otra unidad registra la reclamación de Álvaro de Pareja, suegro de Ramírez, y el requerimiento presentado por el regidor Jaime de Luna en el concejo local ante el corregidor y el alcalde mayor de Cádiz instándoles a no aceptar a Díaz como notario e invocando, al respecto, el incumplimiento de las leyes contrarias a la transmisión de oficios por dinero, más el auto del alcalde declarando perdido el oficio y mandando aplicar su precio al fisco real ${ }^{7}$. La última unidad recoge simplemente la súplica de Díaz al monarca apartándose del pleito y renunciando a sus derechos sobre la escribanía ${ }^{8}$.

\footnotetext{
2 En adelante y al objeto de facilitar la redacción, para calificar a los escribanos públicos del número, equivalentes a nuestros actuales notarios, utilizaremos, indistintamente, los términos de escribano del número y de notario, distinguiéndolos así de los meros escribanos de los reinos, carentes frente a los anteriores de incardinación en un oficio local y con competencia general y atribuciones distintas. Véase BONO HUERTA, José, Historia del Derecho notarial Español, vol I-2, Madrid, 1982, pp. 299-303.

3 ROJAS VACA, María Dolores, "Los escribanos públicos del número en Cádiz según el pleito de la ciudad contra Diego González (1514-1515)”, H(bistoria). I(nstituciones). D(ocumentos), 45, 2018, pp. 301-351.

${ }^{4}$ Idem.

${ }^{5}$ Ibidem, p. 302.

6 A(rchivo) G(eneral de)S(imancas), C(onsejo)R(eal de)C(astilla), 87, 7, I-VII.

7 AGS, CRC, 628, 12.

8 AGS, CRC, 763, 1, 45.
} 


\subsection{Memoriales, peticiones, alegaciones y probanzas}

El 11 de mayo de 1526 los consejeros fallan recibir a prueba lo dicho y alegado por las partes, estableciendo el término de 50 días para hacerla efectiva y presentarla ante el Consejo Real al tiempo que conceden el mismo plazo para que se practique la prueba contradictoriamente?

Memoriales, peticiones y alegaciones exhibidos por los litigantes ante el Consejo, a veces con la justificación documental pertinente, sirven para definir sus posturas, fijar intenciones y defender sus intereses. La intención de ambos queda clara, obtener la merced regia de la escribanía. Las razones argüidas son, por lógica, dispares. Mientras Díaz esgrime básicamente las amenazas y coacciones recibidas e irregularidades formales al renunciar el oficio, de ahí su contradicción ${ }^{10}$, Ramírez alega engaño, desconocimiento de la ley y daño para su esposa al otorgar la suya y, en consecuencia, considera la provisión de Díaz obtenida subrepticiamente, esto es, con ocultación de los hechos y con relación no verdadera ${ }^{11}$.

Al mismo fin obedecen las probanzas de interrogaciones de los testigos llamados por los pleiteantes. Evidentemente, las declaraciones de los testigos, en consonancia con las cuestiones planteadas, benefician a la parte representada, haciendo hincapié en los aspectos más favorables a sus respectivos intereses o, en su caso, más desfavorables para la parte contraria.

De este modo la probanza de Díaz, elaborada y concluida en Sevilla el 23 de mayo de 1526 ante el escribano de los reinos Cristóbal de Oneto, será elevada al Consejo, en Granada, el 26 de junio. Consta de 31 preguntas $^{12}$ a las cuales responden 36 testigos $^{13}$. Con

\footnotetext{
9 AGS, CRC, 87, 7-I, sf.

10 Apéndice docs $n^{\circ} \mathrm{s} 3,4,6$.

${ }^{11}$ Apéndice docs $n^{\circ}$ s $2,7,8$.

12 Anexo 4.1.

${ }^{13}$ Los 36 testigos llamados por Díaz son los que enumeramos a continuación: Francisco Vázquez, alcalde de la cárcel, vecino de Cádiz (35 años); Pedro Cabrón, regidor, vecino de Cádiz (19); Gerónimo de Quirós, corredor de lonja, vecino de Cádiz (33); Francisco García, hijo de don García de la Cerda, vecino de El Puerto de Santa María, estante en Cádiz (19); Alonso Montote, hijo de Juan Montote, vecino de Cádiz (18); Cristóbal Díaz, hijo de Jorge Díaz, vecino de Cádiz, primo de Cristóbal Díaz (24 o 25); Antonio de Urdiales, vecino de Cádiz (38); Amigo de Amar, vecino de Cádiz (25); Juan de la Barrera, hijo de Rodrigo de Jerez, vecino de El Puerto de Santa María, estante en Cádiz (19); Martín Ruiz de Gaínza, criado de Diego Sánchez, escribano público de Cádiz (16); Lope de Medina, escribano público del número de Cádiz (50); Alonso de Isla, recaudador de las alcabalas de Cádiz, vecino de Andújar (70); Alonso Galíndez de Amar, vecino de Cádiz (35); bachiller Antón de Frías, vecino de Cádiz (28-29); Diego Ortiz, alguacil de Cádiz (24); Diego Sánchez de Cádiz, alcalde de la fortaleza y regidor de Cádiz (50); Jácome Justinián, mercader de Egio, estante en Cádiz (30); Pedro de Cardona, alguacil de Cádiz (30); Hernán Gascón, escribano del cabildo, vecino de Cádiz (36); Pedro Marrufo, regidor, vecino de Cádiz (21); Cristóbal Rafael, procurador, vecino de Cádiz (41); Diego Sánchez de Argumedo, regidor, vecino de Cádiz (34); Pedro Sánchez de Estopiñán, regidor, vecino de Cádiz (23); Francisco de Nava, sedero, vecino de Cádiz (40); Diego Sánchez Bernalte, regidor, vecino de Cádiz (50); Juan Ochoa, vizcaíno, criado de
} 
edades comprendidas entre 17 y 70 años, en su mayoría vecinos de Cádiz, desde la óptica socio-profesional, cuando se menciona y frente a los de su adversario, hallamos una nutrida representación de oficios relacionados con el gobierno municipal, a saber, seis regidores, dos alcaldes, un alguacil y un escribano de cabildo. Entre las profesiones liberales encontramos un bachiller en leyes, un procurador de causas y tres escribanos del número. Cierran la lista un mercader y, entre los artesanos, un sedero. Un clérigo representa al estado clerical.

Por su parte, son dos las probanzas exhibidas por Ramírez. Una fue elaborada en Jerez de la Frontera ante Antón García del Pecho, signada, asimismo, de Luis de Llanos, ambos notarios de Jerez, y concluida el 28 de mayo ${ }^{14}$. La otra, realizada en Cádiz ante Lope de Medina, suscrita también por el notario Diego Sánchez, era librada el 18 de junio. Ambas fueron presentadas al Consejo en Granada el 25 de junio. En el interrogatorio formulado por Ramírez, compuesto por 13 preguntas ${ }^{15}$, declaran 50 testigos $^{16}$. Con edades entre los 22 y los 73 años tales testigos también son fundamentalmente vecinos de Cádiz. Desde el punto de vista socio-profesional, a diferencia de lo que sucede con los de Díaz, se adscriben con

Alonso de Medina, escribano del número de Cádiz (17); Diego Sánchez de Sanabria, regidor, vecino de Cádiz (40); Juan de Barrán, vecino de Cádiz (27); Agustín Sauli, vecino de Cádiz (24); Lorenzo Fernández, alguacil del obispo de Cádiz, arrendador del pasaje, vecino de Cádiz (+60); Antonio Parrado, vecino de Cádiz (45); Diego Sánchez, escribano público del número, vecino de Cádiz (36); Alonso de Fuentes, vecino de Cádiz (+25); Pedro de Medina, vecino de Cádiz (50); Alonso García, clérigo, vecino de Cádiz (27); Alonso de Medina, escribano público del número de Cádiz (32).

14 Esta probanza carece de las preg(untas) 8, 9 y parte de la 10 de la probanza siguiente. A las 11 cuestiones que la componen responden sólo dos testigos: Luis de Estopiñán y Nuño de Cepeda.

15 Anexo 4.2.

${ }^{16}$ Los 50 testigos presentados por Ramírez son: licenciado Juan Pérez (34 años); Antón Fernández de Sierra, racionero de las iglesias de Cádiz y Algeciras (40); Fernando de Haya, hijo de Francisco Fernández Duque, barbero, vecino de Cádiz (50); Martín Alonso de Toledo, mercader, vecino de Cádiz (+45); Diego Ramírez, procurador de causas, vecino de Cádiz (37); Cristóbal de Vega, procurador de causas, estante en Cádiz (40); Francisco Camacho, hijo de Bartolomé Suárez, difunto, vecino de Cádiz (30); Pedro Lorenzo, vecino de Cádiz, compadre de Diego Ramírez (24); Juan Moreno, zapatero, vecino de Cádiz (53); Francisco Calar, procurador, vecino de Cádiz (31); doctor Pedro de Tarifa, médico, vecino de Cádiz (33); Juan de Castilla, estante en Cádiz (40); Cristóbal de Santillán, vecino de Cádiz (35); Alonso de Barrán, estante en Cádiz, (26); Francisco Rodríguez, corredor de lonja, vecino de Cádiz (50); Tomás de la Cajina, vecino de Cádiz (22); Bartolomé de Capilla (47); Pedro de Espinosa, vecino de Cádiz (34); Lorenzo García, vecino de Cádiz (50); Alonso Bejarano, estante en Cádiz (50); Gaspar García (23); Francisco Fernández Duque, barbero (50); Miguel Mora, mercader, estante en Cádiz (25); Gonzalo Fernández, especiero, vecino de Cádiz (60); Juan Moreno, librero, vecino de Cádiz (38); Cristóbal de Vitoria, vecino de Cádiz (50); Fernando de Jerez (50); Álvaro de Pareja, vecino de Cádiz (50); Luis de Alcahudete, médico, vecino de Cádiz (60); Manuel Ferraz, escribano público del número de Cádiz (24); Juan Díaz, vecino de Cádiz (45); Pedro Rodríguez, espartero, vecino de Cádiz (40); Francisco de la Torre, vecino de Cádiz (50); Cristóbal Rafael Italián, vecino de Cádiz (42); Francisco Gil, sastre, vecino de Cádiz (+50); Francisco de Afiesco, vecino de Cádiz (60); Juan de Mayorga, cambista, vecino de Cádiz (42); Diego de Medina, vecino de Cádiz (60); licenciado Diego Téllez, alcalde mayor de Cádiz (40); Jaime de Luna, veinticuatro de Jerez y regidor de Cádiz, vecino de Cádiz (45); Pedro Gil, estante en Cádiz (50); Jaime de Ralfás, mercader aragonés, estante en Cádiz (26); Diego Cordero, fraile de la orden de Santo Domingo (40); Antón Galindo (70); Pedro Buenhijo, vecino de Cádiz (73); Beatriz Martínez, vecina de Cádiz (74); Leonor Sánchez, viuda de Diego de Contreras, difunto, vecina de Cádiz (45); Leonor Bernal, beata de la tercera orden de Santo Domingo, profesa (55); Beatriz de Salazar, beata de la orden de San Roque Domingo, profesa, estante en Cádiz (40); licenciado Luis Estopiñán, clérigo presbítero, vecino de Cádiz (44); Nuño de Cepeda, cuyo padre es pariente de Ramírez en cuarto grado (25).

Trocadero, no 31 (2019), ISSN 2445-267X, pp. 1-48 
preferencia al artesanado (zapatero, barbero, sastre, especiero, espartero y librero). En menor medida figuran oficios relacionados con el Ayuntamiento (regidor, alcalde mayor y alguacil) y entre las profesiones liberales encontramos un escribano del número y dos licenciados en leyes, tres procuradores de causas y un médico. Cierran la lista dos mercaderes y un cambista. La iglesia aparece representada por un clérigo presbítero, un racionero de las iglesias de Cádiz y Algeciras, un fraile de Santo Domingo y dos beatas profesas de la misma orden.

En cuanto a los escribanos del número conviene señalar que, entre los testigos de Díaz, deponen tres notarios locales, uno de los cuales era su hermano, Alonso de Medina. Si consideramos que los oficios notariales de Cádiz en 1526 son siete y que uno de ellos pertenecía a Diego González, también hermano suyo, Cristóbal Díaz tenía de su lado a la mayoría del colectivo notarial gaditano. Al contrario, propuesto por Ramírez, tan sólo testifica un notario, lo cual confirma su menor estima o predicamento dentro de este grupo profesional, de otra parte integrado en su conjunto por individuos bastante jóvenes y cuyas edades relacionamos a continuación: 50 años (Lope de Medina), ¿42? ${ }^{17}$ (Fernán Sánchez), 36 (Diego Sánchez), $36^{18}$ (Diego Ramírez de la Rúa), 32 (Alonso de Medina), ¿26? ${ }^{19}$ (Diego González) y 24 (Manuel Ferraz).

La información derivada de los memoriales, peticiones, alegaciones y, especialmente, de las probanzas posibilita la reconstrucción de los hechos.

\subsection{Hechos}

El detonante del pleito lo constituye la renuncia del oficio que Díaz, aún sin haber tomado posesión ante el concejo, se vería obligado a otorgar en beneficio de Ramírez, su antecesor. No obstante, el desencadenante mediato lo podemos situar con anterioridad en la venta y renuncia que del oficio hizo Ramírez a favor de Díaz y en su posterior reclamación y contradicción.

En efecto, aficionado al juego de naipes o, como trataba de demostrar Díaz, jugador empedernido e impelido por las deudas, Ramírez vende la escribanía a Díaz por 575 ducados. Según confiesa, lo hace creyendo que lo podía fazerer, sin tener notiçia que por las leyes destos reinos y capitulos de Cortes está proybido ${ }^{20}$, y obviando, como declara en cabildo su mujer, Inés de Pareja,

\footnotetext{
${ }^{17}$ Habida cuenta de que accede al oficio en 1502, calculamos su edad partiendo de 18 años, ROJAS VACA, María Dolores, op. cit., 345-346.

18 Ibidem, p. 329.

${ }^{19} \mathrm{Idem}$, sabemos que en 1515, cuando accede al cargo, era menor. Partimos, pues, de los 17 años.

20 AGS, CRC, 628, 12, sf.
} 
el gran daño e perjuizio que dello se sygue a mi persona e honrra e a mi dote porque hallará vuestra merçed que el dicho Diego Ramírez ovo el dicho ofiçio con mis bienes dotales ${ }^{21}$ y sy agora esto pasase yo quedaría perdida e destruyd $a^{22}$. Concurren pues en el convenio dos anomalías, cuales son el hecho de que el notario enajenara un bien que no era suyo ya que, en concepto de dote, pertenecía a su esposa y no puede el marido enagenar, vender ni malvaratar la dote ${ }^{23}$, y la venta del oficio propiamente dicha, negocio realizado al margen de la ley por su carácter oneroso y penado con la pérdida del oficio para el vendedor y la confiscación del precio pactado para el comprador ${ }^{24}$. Con estos presupuestos y apremiado por la familia y ciertas autoridades afines, reclama e impugna la renunciación otorgada ${ }^{25}$.

$\mathrm{Al}$ respecto de la afición o adicción de Ramírez al juego de cartas son significativas y unánimes las deposiciones de la mayoría de los testigos de Díaz. Además de ratificar el hecho, inciden en las consecuencias negativas para su quehacer profesional con el consiguiente abandono del oficio, de la audiencia y de la clientela:

... ha tenido e tyene por vso e costunbre de jugar muchas e diversas bezes e todas las vezes que tyene dineros no dexa de jugar porque este testigo le a visto jugar e jugado con él muchas vezes, asý de día como de noche, con muchas personas e muchos dineros e que a visto que el dicho Diego Ramírez a dexado de vsar e resydir en el dicho ofiçio de escrivanía por jugar e que, asimismo, a visto que algunas personas que an tenido negoçios ante él le han andado a buscar para cosas que cunplian a sus pleytos e buscarle en su casa y estar jugando e mandarse negar y que esto que lo sabe porque este testigo lo ba visto (Pedro Marrufo, vecino y regidor de Cádiz, preg. 29).

... sabe que el dicho Diego Ramírez, tiene por costunbre de ser tabúr e jugador e que juega muchas cantidades de dineros y esto que lo sabe porque este testigo, theniendo negocios ante él, biéndole a buscar a su casa se mandó negar y después este testigo le vio por entre la puerta que estaba jugando con Françisco de León e con un Barrán e con otros vezinos desta dicha çibdad e que esto es ansý público e notorio en esta dicha çibdad (Jácome Justinián, mercader genovés, estante en Cádiz, preg. 29).

\footnotetext{
${ }^{21} \mathrm{La}$ carta de dote en Apéndice doc no 1 . El testigo Francisco Rodríguez, corredor de lonja, avecindado en Cádiz y de 50 años, tras confesar que estuvo presente en los desposorios y velaciones del matrimonio, declaraba que vio cómo Álvaro Pareja “dio çiertos bienes en casamiento al dicho Diego Ramírez e que no los vido apreçiar ni sabe lo que valieron e vido cómo el dicho Álbaro de Pareja fue a la Corte por el ofiçio de escriuano público e se lo traxo", AGS, CRC, 87, 7-I, 19v.-20r.

22 AGS, CRC, 87, 7-I, fol 14r.-v.

23 JORDÁN DE ASSO, Ignacio; MANUEL Y RODRÍGUEZ, Miguel de, Instituciones del Derecho Civil de Castilla, Madrid, 1792, pp. 53-55, recogen la prohibición remitiendo a P(artida) 4, Tít(ulo) 2, L(ey) 7 y, en la misma línea, VILLADIEGO VASCUÑANA Y MONTOYA, Alonso de, Instruccion politica y practica iudicial conforme al estilo de los consejos, audiencias y tribunales de Corte y otros ordinarios del reyno: utilissima para los gouernadores y corregidores y otros inezes ordinarios..., Madrid, 1747, p. 397.

${ }^{24}$ N(ueva) R(ecopilación) Lib(ro) 7, T(ítulo) 2, L(ey) 8, Los Reyes Católicos, según pragmática dada en Madrid en 1494, "que prouee más estensamente en castigar a los que venden o compran los oficios que se han de dar por votos por los concejos y a los que los renuncian por dinero".

${ }^{25}$ Ramírez en su reclamación sitúa la fecha de la renuncia en 13 de febrero, Apéndice doc $n^{\circ} 2$.
} 
... sabe que el dicho Diego Ramírez es persona que a tenido e tiene por costunbre de ser público tabúr e que sabe que juega e a jugado muchos dineros con muchas personas e que esto que lo sabe este testigo porque muchas vez̧es le a visto jugar e porque ansý es público e notorio en esta dicha çibdad que cree este testigo que si no oviese jugado que valdría su hazienda más de mill castellanos de oro más de lo que vale e que a paresscer deste testigo syendo el dicho Diego Ramírez jugador o tabúr, como dicho a, no puede resydir bien en el dicho ofiçio de escrivanía. E que vio este testigo que muchas vezes personas que ante él traýan pleytos yrle a buscar a su casa e al abdiençia e no le hallar a cabsa destar jugando. E que sabe que el dicho Diego Ramirez. devia treynta o quarenta mill maravedíes por vn contrato público de los quales hera fiador Francisco de la Torre, vezino desta çibdad, e que vio este testigo que, como el dicho Françisco < de la Torre> supo que el dicho Diego Ramírez avía vendido el escrivanía, acudió al dicho Diego Ramirez a que pagase la dicha debda de que estava por fiador e le sacase de la fiança e que esto respondió el dicho Diego Ramirez: que si vendía el ofiçio era por salir de debdas e para yrse a bivir a Granada e conprar alli un ofiçio (Francisco de Nava, sedero, vecino de Cádiz, preg. 29).

Asimismo, la condición de tahúr, dado el exceso de juego y la poca fortuna, le conduce al endeudamiento. De hecho, la última declaración nos permite enlazar con el estado de su hacienda que si no oviese jugado que valdría ... más de mill castellanos de oro más de lo que vale ${ }^{26}$. A causa del vicio queda ésta maltrecha y plagada de deudas, lo que le llevará a hipotecar buena parte de sus bienes, entre ellos el oficio y, en fin, para saldarlas, a venderlo con la intención última de marcharse de Cádiz y empezar nueva vida en Granada. Por igual motivo y huyendo de los acreedores y de la justicia, se vio obligado a refugiarse en dos ocasiones ${ }^{27}$ y en tienpos pasados que a hartos días este testigo vyo al dicho Diego Ramírez. retraýdo en la yglesia de la Misericordia ${ }^{28}$ por devdas que debia ${ }^{29}$, e incluso parece que por impago llegó a estar preso en la cárcel pública de la ciudad ${ }^{30}$. Sirvan como botón de muestra de su situación económica, además del precedente, los ejemplos que se relacionan seguidamente:

... sabe que conviene más al serviçio de su Magestad e al desta dicha çibdad que el dicho Cristóbal Díaz tenga el dicho ofiçio de escriuano sobre que es este dicho pleyto que no el dicho Diego Ramirez. e que esto que lo save porque tiene el dicho Diego Ramírez apotecado ${ }^{31}$ el dicho ofiçio de escrinano e todos sus bienes al dicho Jaime de Luna por dozientos ducados que el dicho Jaime de Luna le prestó e porque sy el dicho Diego Ramírez quedase por escrinano, como es criado e allegado e debdor del dicho Jaime de Luna, vendría mucho perjuyzio e daño a los vezinos desta dicha çibdad porque todas las cosas que tocasen al dicho Jayme de Luna pasarían ante él e se harían como el dicho Jayme de Luna quisiese e serian en perjuyzio desta dicha çibdad (Pedro Cabrón, vecino y regidor de Cádiz, preg. 21).

\footnotetext{
${ }^{26}$ Francisco de Nava, sedero, vecino de Cádiz, preg. 29.

27 Diego Sánchez Bernalte, vecino y regidor de Cádiz, preg. 29.

${ }^{28}$ HEVIA BOLAÑOS, Juan de, Curia Philipica, Madrid, 1797, vol 1, p. 211: "Goza la iglesia de su inmunidad para en quanto amparar los retraídos que a ella se acogen y no poder ser sacados de ella siendo constituída con autoridad del Prelado".

${ }^{29}$ Hernán Gascón, escribano del cabildo y vecino de Cádiz, preg. 29.

30 Diego Sánchez Bernalte, vecino y regidor de Cádiz, preg. 29; Diego Sánchez, escribano del número y vecino de Cádiz, preg. 29; Cristóbal Rafael, procurador y vecino de Cádiz, preg. 29.

31 Sic.
} 
... Diego Ramírez deve al dicho Jayme de Luna más de dozientos ducados de oro por los quales el dicho Diego Ramírez le tiene obligado e ypotecado el ofiçio de escriuanía sobre que se litiga (Cristóbal Díaz en la relación de testigos refutados y sus causas, fol 54r. $)^{32}$.

Lógicamente, la reclamación de Ramírez encuentra la oposición de Díaz quien de regreso a la ciudad, tras haber acudido con su hermano, González, a la Corte en Sevilla para negociar la expedición del título ${ }^{33}$, vivirá, incrédulo, una auténtica pesadilla. Y es que, en su ausencia, Ramírez se confabula con el lugarteniente del corregidor, licenciado Diego Téllez, poseedor de la vara de la justicia, y con su amigo, el regidor Jaime de Luna, rico e poderoso,... sabio e mañoso, fuera de letras porque no es letrado ${ }^{34}$, quien prometió que avía de poner su estado e haz̧ienda para que yo no fuese resçibido al dicho ofiçio por enemistad que me tiene ${ }^{35} \mathrm{y}$ que, abusando de su poder, hacía y deshacía en el lugar a su antojo:

... sabe que el dicho Jaime de Luna es muy rico e sabio e mañoso e que sabe que el dicho Jaime de Luna baze lo que quiere en esta dicha çibdad y esto que lo sabe este testigo porque ansý lo a visto e por tal le a visto tener en esta dicha çibdad como la pregunta dize e porque la mayor parte desta çibdad le debe dineros e porque quando les presta a los vezinos desta dicha çibdad se los presta con juramento que le hazen de no serle desfavorables ni contra él. E esto que lo sabe porque lo a visto e porque ansý es público e notorio en esta dicha çibdad e porque oyó dezir a Hernando Gascón, escrinano de cabildo desta çibdad, e a Sancho de Aya, canónigo de la yglesia de Santa Cruz desta dicha çibdad, que porque el dicho Jaime de Luna avía prestado çiertos dineros a vn Martín de Haya, regidor, hermano de los en esta çibdad susodichos, el dicho Jaime de Luna quando se los //r. prestó biz̧o bazer escritura con juramento al dicho Martín de Aya, regidor, e al dicho Hernando Gascón e a Sancho de Aya e Pedro de Aya, canónigo desta çibdad, hermanos del dicho Martín de Aya, regidor, e que no le fuesen contrarios ni desfaborables en quantas cosas pudiesen (Alonso Galíndez de Amar, vecino de Cádiz, preg. 4).

Por tanto, trataban de impedir que Díaz fuera admitido como tal notario por el Ayuntamiento. A este fin, juntos, urdían un plan basado en la fuerza, amenazas y extorsiones cuya puesta en ejecución se concretaba, inicialmente, en prender y encarcelar a Alonso de Medina, el hermano de Díaz que había permanecido en la ciudad, porque no quería declarar por quánto se avía vendido el ofiçio de escrivanía sobre que es este pleito y estuvo preso en la cárçel pública desta çibdad ${ }^{36} \mathrm{o}$, dicho de otro modo, por los negoçios e diferençias que su hermano, Christóval Diaz, traía con el dicho Diego Ramírez sobre la dicha escrivanía ${ }^{37}$. Al mismo tiempo procuraban el apoyo de los

\footnotetext{
32 Señala hipoteca sobre el oficio sin especificar Francisco García, hijo de don García de la Cerda, vecino de El Puerto de Santa María, estante en Cádiz, preg. 21.

${ }^{33}$ El título está datado en 16 de marzo, véase ROJAS VACA, María Dolores, op. cit., anexo, p. 346.

34 Bachiller Antón de Frías, preg. 4.

35 Apéndice doc $\mathrm{n}^{\circ} 4$.

${ }^{36}$ Diego Ortiz, alguacil, preg. 12.

${ }^{37}$ Alonso Montote, hijo de Juan Montote, vecino de Cádiz, preg. 12.
} 
vecinos $^{38} \mathrm{y}$, sobre todo, el oportuno consenso de los demás regidores para anular el cabildo inmediato que se había de celebrar el viernes, 23 de marzo ${ }^{39}$, pues es vso e costunbre vsada e guardada de veynte años e más tienpo, que este testigo se acuerda, de hazer cabildo en esta dicha çibdad, la justiçia e regidores della, cada viernes hordinariamente ${ }^{40}$. A contrarrestar esta influencia responden dos cartas de súplica remitidas al rey, una por el síndico procurador, como representante de los vecinos, y la otra por once regidores de la ciudad en las cuales, alegando que Diego Ramírez fizo firmar no ynformando de lo en la petición contenido a los que asý firmaron, solicitaban del monarca la confirmación de Díaz como escribano del número local ${ }^{41}$.

Sea como fuere, alertado por el alguacil Pedro de Cardona, quien le confesaba que sospechava y creeya que a todos tres hermanos avían de prender, Medina escribía una carta de aviso a sus hermanos para que no entrasen en esta çibdad de dia salvo de noche y secretamente para que se negoçiase lo que cunplía al dicho Christóval Día ${ }^{42}$. De esta forma, Diego González y Cristóbal Díaz hacen su entrada nocturna en Cádiz el jueves, 22 de marzo, de la semana de Ramos ${ }^{43}$. Para evitar la cárcel y ante las condiciones atmosféricas adversas que reinaban en la localidad e imposibilitaban la huida ya que la dicha çibdad de Cádiz es ysla çercada de mar e que save que no pueden salir della por tierra syno por agua y esto que lo save este testigo porque lo a visto y ansý es público e notorio e que sabe que dende el viernes, contenido en la pregunta, fasta la Pascua, en la pregunta contenida, bizo rezios tienpos en esta dicha çibdad de levante e tormenta que estuvieron los pasajes e varcos çinco o seys días que no pasavan, e otras vezes quatro días e tres dias, e que sy alguno pasaba en el dicho tienpo pasaba con mucho temor e peligro y esto que lo save este testigo porque lo vio e porque este testigo es arrendador del

\footnotetext{
${ }^{38}$ Los vecinos y moradores de Cádiz que piden a los reyes que Ramírez quede como notario en la ciudad y que Díaz, mayoritariamente, califica como criados, paniaguados y familiares de Luna son: Lope de Portillo [...], Fernán Díaz, Juan Díaz, Pedro de Medina, Luis Hernández, maestre, Alonso de Fuentes, Blas de Frías, Rodrigo de Goyán, Pedro de Escobar, Cristóbal Rafael, Cristóbal Coronado, Gaspar de Frías, Antón Núñez, Juan [...], Juan Batista Franco, testigo, el doctor Alcau[dete], G[aspar de] Olmedo, Bartolomé de Treviño, Ambrosio de Casana, Francisco de Varea, Gregorio Perrachín, Juan de Mayorga, Juan de Gatica, Pedro Martín de Palma, Polo Centurión, Fernando de Argumedo, Roberto de Dique, Juan de Sevilla, Pero Martín Pocasangre, Bartolomé Sofía, Alonso García, clérigo, Jaime Castelo Elduque, Francisco Sauli, Cristóbal Camacho, Jaime Fijaime, Cristóbal Sánchez, Lope Rodríguez, Pedro de Espinosa, Fernán García de Trujillo, Juan Jinete, Pedro de Luna, menor, Juan Bernal, boticario, Antón Martín Parrado, Gonzalo Díaz, cirujano, Bartolomé Capilla, Antón Thomás, Miguel Mora, menor, Antón Galíndez, Diego Ortiz, Antón Galíndez, Pedro de Valladolid y Diego Ramírez, procurador de Cádiz (Cristóbal Díaz, interrogatorio, preg. 24).

${ }^{39}$ Señalan, además del viernes, como día ordinario de cabildo, el lunes los testigos Hernán Gascón, vecino de Cádiz y escribano del cabildo, preg. 17, 19; Diego Sánchez de Argumedo, preg. 17; Diego Sánchez Bernalte, vecinos y regidores de Cádiz, preg. 17: "lo a visto vsar e guardar de más de veynte e çinco años que a que este testigo es regidor desta çibdad".

${ }^{40}$ Alonso Galíndez de Amar, preg. 17.

${ }^{41} \mathrm{La}$ carta de los vecinos en AGS, CRC, 87, 7-I, sf. La súplica de los regidores en Apéndice doc no 9.

${ }^{42}$ Alonso de Medina, preg. 12.

${ }^{43}$ Francisco Vázquez, vecino de Cádiz, alcalde de la cárcel, Pedro Cabrón, vecino y regidor de Cádiz, Francisco García, hijo de don García de la Cerda, vecino de El Puerto de Santa María, estante en Cádiz, Cristóbal Díaz, hijo de Jorge Díaz, vecino de Cádiz, primo de Cristóbal Díaz, Amigo de Amar, vecino de Cádiz, Juan de la Barrera, hijo de Rodrigo de Jerez, vecino de El Puerto de Santa María, estante en Cádiz, Pedro Marrufo, vecino y regidor de Cádiz y Diego Sánchez de Argumedo, vecino y regidor de Cádiz, preg. 17.
} 
pasaje desta dicha çibdad e que a esta cabsa estava detenida mucha gente en esta dicha çibdad que no podía salir $^{44}$, Díaz acude a casa del bachiller Frías. Allí, en secreto, Hernando Gascón, escribano del cabildo, llamado al efecto, aconseja la mediación del provisor del obispado, Juan Pablo Oliveira, al cual encontraron hažiendo colaçión o çenando que era de noche ${ }^{45}$. Al día siguiente, este en compañía de González se entrevista con Luna en dos ocasiones, en la iglesia de Santa Cruz tras el sermón, la primera, y en la plaza de la Corredera, la segunda. Sin embargo, no consigue que ceje en su decisión, razón por la cual sugiere a los hermanos plegarse a la intención de Luna, esto es, que Díaz renuncie al oficio a cambio de la devolución del precio pagado y, a lo sumo, de las costas o gastos derivados de su tramitación que habían de ser tasadas y moderadas por el provisor ${ }^{46}$.

Así las cosas, Díaz busca amparo en la iglesia de Santa Cruz donde los alguaciles por orden del lugarteniente le esperan y cercan para, caso de salir, prenderle y llevarle a un lugar en el cual no pudiese presentar la provisión regia. Como cabsas livianas pasadas ${ }^{47}$ califica la razón de los mandamientos de prisión dados en su contra, mientras los testigos de Ramírez aluden a un delito previo de mayor entidad:

... lo que sabe...es que el dicho Christóval Díaz vbo çierta qüestión con vn Gaspar de Aya, vezino desta çibdad, en que el dicho Christóval Díaz le dio vna cucbillada en vna mano e que fue la qüestión sobre razón de un perquet8 que dezían que el dicho Christóval Díaz avía echo, por la qual cucbillada dio mandamiento el dicho teniente para prenderle y el dicho Christóbal Díaz se presentó ante el dicho teniente en un aposyento que está sobre la cárcel desta dicha çibdad que es donde este testigo posa e que cree este testigo que se despachó allí de lo que tocava a lo de la cuchillada que avía dado al dicho Gaspar de Aya porque este testigo le abló luego que el dicho teniente le avjá despachado y el dicho Christóval Diaz le dixo a este testigo ya me despachado ${ }^{49}$ el teniente y este testigo le dixo que holgava mucho dello. E que, después desto, antes que el dicho Christóval Díaz biniese de la Corte a esta dicha çibdad, el dicho teniente dio mandamiento para prender al dicho Christóval Díaz por razón de un perque que dezian que avía hecho sobre que avia avido la dicha qüestión con el dicho Gaspar de Aya, al qual dicho mandamiento este testigo se refiere, que está en poder de Diego Hurtiz, alguazil desta çibdad e conpañero deste testigo, e a la pesquisa que sobre ello se tomó por donde el dicho mandamiento se dio (Pedro de Cardona, alguacil de Cádiz, preg. 9).

\footnotetext{
${ }^{44}$ Lorenzo Fernández, vecino y alguacil del obispo de Cádiz, arrendador del pasaje, preg. 30. Sobre el pasaje Cádiz-El Puerto de Santa María y otros véase ROJAS VACA, María Dolores, "El pasaje de la ciudad de Cádiz a la villa de El Puerto de Santa María y otros pasajes entre los siglos XVI y XVII", Trocadero: Revista de bistoria moderna y contemporánea, $\mathrm{N}^{\circ}$. 30, 2018, pp. 121-146.

${ }^{45}$ Bachiller Antón de Frías, vecino de Cádiz, preg. 28.

${ }^{46}$ Diego Ramírez, interrogatorio, preg. 3 aunque atribuye la tasación de las costas, también, a Jaime de Luna; Francisco Camacho, hijo de Bartolomé Suárez, difunto, vecino de Cádiz, preg. 2.

${ }^{47}$ Cristóbal Díaz, interrogatorio, preg. 9.

${ }^{48}$ El Diccionario de Autoridades define perque como "libelo infamatorio".

${ }^{49}$ Sic.
} 
Sufre de este modo, tanto él como sus hermanos, conforme narra, toda suerte de intimidaciones y extorsiones que, según los testigos de Díaz, justifican el temor de los mismos al estimar que, cuando Luna y Téllez llevan a la práctica sus amenazas, las consecuencias pueden llegar a ser nefastas. Prueba de ello son los supuestos que los testigos relacionan y que exponemos a continuación:

... save que el dicho Jayme de Luna suele e acostunbra poner en execuçión sus amenaz̧as, como es notorio, e que lo save porque a un Antón Galindez, vezino desta dicha çibdad, dieron de palos e a vn Pedro Andrea, conpañero del dicho Jayme de Luna, vna cuchillada por la cara e a vn Juan Ochoa, carniçero, vezino desta dicha çibdad, porque no dio tan aýna carne a vn su esclavo, le dio vna cuchillada por la cara. Y esto, ansý los palos como cuchilladas, lo hizieron dos esclavos del dicho Jayme de Luna e vn escudero suyo y dizen públicamente en esta dicha çibdad que se hizo por mandado del dicho Jayme de Luna (Diego Sánchez Bernalte, vecino y regidor de Cádiz, preg. 13).

... oyó dezir e publicar al dicho capellán del dicho Jayme de Luna que el dicho teniente y el dicho Jayme de Luna ponian muchos temores e amenazas, asý con el dicho Christóbal Diaz como contra los dichos sus hermanos, e que según los temores e amenazas que este testigo oyó al dicho capellán que los dichos teniente e Jayme de Luna hazian e ponian a los susodichos, e a cada vno dellos, e teniendo el dicho teniente la vara de justiçia de teniente de corregidor en esta dicha çibdad e syendo poderoso en ella el dicho Jayme de Luna, como es a paresser deste testigo, el dicho Christóbal Díaz. e sus hermanos, e cada vno dellos, podían y devían tener justo temor e miedo de los dichos teniente e Jayme de Luna e a oýdo dezir que las amenazas que el dicho Jayme de Luna suele hazer a las vezes las pone en execuçión, espeçialmente en un Antón Galinder, vezino desta dicha çibdad, que le mandó dar de palos a sus criados e ge los dieron e que nunca vbo sobre ello ningún castigo de justiçia e que esto que lo a oýdo dezir a vn Pedro de Medina, sastre, vezino desta dicha çibdad, e a Françisco de la Torre, vezino desta dicha cibdad, e a otras muchas personas de cuyos nonbres dellas este testigo no se acuerda (Cristóbal Díaz, hijo de Jorge Díaz, vecino de Cádiz, primo hermano de Cristóbal Díaz, preg. 13).

... a su pareçer, aviendo becho las amenazas e temores y estorsyones que dicho tiene, que a oýdo dezir que los dichos teniente e Jayme de Luna hazián al dicho Christóual Díaz e a los dichos Diego Gonçález. e Alonso de Medina, sus hermanos, que ellos e cada vno dellos podían tener justo temor e miedo por tener como tiene el dicho teniente la vara de justicia en esta dicha çibdad e por ser el dicho Jayme de Luna poderoso en esta dicha çibdad como dicho ha. E que sabe que el dicho Jayme de Luna suele poner sus amenazas en execución e que lo sabe porque este testigo vio venir a vn pariente del dicho Jayme de Luna, que no se acuerda como se llama, que traía cortadas las narizes y entranvos carrillos e que se las avía cortado un Domingo, sobrino del dicho Jayme de Luna, e que aquél que benía con las narizes cortadas dezía bien me temía yo desto e que oyó dezir este testigo al que ansý venía cortadas las narizes e a otras muchas personas públicamente que por pendençia vieja que el dicho Jayme de Luna tenía con él le avía fecho lo susodicho el dicho Domingo, sobrino del dicho Jayme de Luna, e que $<$ después> vio este testigo como el dicho Jayme de Luna favoresçía al dicho Domingo, su sobrino, e le dava vn caballo en que andwviese e porque después que pasó lo susodicho el dicho Jayme de Luna andava aconpañado de gente de guarda e armado con armas fuertes por cabsa de lo susodicho y esto que lo sabe este testigo porque bio que el dicho Jayme de Luna traj́a armas secretas e porque vyo la dicha gente de guarda que con él andava (Alonso Galíndez de Amar, vecino de Cádiz, preg. 13). 
El 24 de marzo, siguiendo la recomendación del provisor y ante la intimidación constante a la que se ven sometidos, Diego González y Alonso de Medina, estando en el poyo de la audiencia, envían llamar a Díaz y, llegado, le comunican que no hay opción, que debe renunciar al oficio por tirarse de embaraços y poner a riesgo lo que no tenian ${ }^{50}$ a lo cual se niega rotundamente. Persiste en su negativa hasta que el dicho Diego Gonçález. lo tomó de la mano y lo sacó del avdiençia e, yendo hazia casa del dicho Jayme de Luna, Christóval Díaz se entró en la yglesia de la Misericordia e alli, tornando a porfiar con él, el dicho Christóval Díaz no quería hasta que el dicho Diego Gonçález, su hermano, lo sacó a renpuxones de la dicha yglesia y fueron a casa del dicho Jayme de Luna ${ }^{51}$. Una vez en casa de Luna, presente el lugarteniente, a ora de býsperas ${ }^{52}$. Cristóbal Díaz otorga, finalmente, cumpliendo la voluntad de aquéllos, la renuncia del oficio a favor de Diego Ramírez sin que yo hablase palabra, chica ni grande, más de quanto dixe al dicho Jayme de Luna por qué me avía sido tan contrario en este negocio y en mis meneos e senblante mostrava e mostré que forçado e contra mi voluntad faz̧ía la dicha renunçiaçión $n^{53}$.

No obstante, antes del acto en torno a las 11 o 12 del mediodía, Díaz se las ingeniaba para presentarse en las casas de su morada del notario Diego Sánchez, que tenía puesta la mesa para comer ${ }^{54}$, con el fin de otorgar acta de reclamación ${ }^{55}$. Pero, teniendo el escribano en su mano el auto que Díaz traía ordenado y queriéndolo leer, irrumpió su hermano, Alonso de Medina, quien por los temores y extorsyones había ido tras él y, reprobando a Díaz que donde ély su hermano estavan no avian de consentyr que el dicho Christóual Díaz fiziese el dicho abto ${ }^{56}$, no se lo permitió otorgar

... porque no fuesen más molestados ni fatigados, y el dicho Christóval Díaz dixo que, avnque alli no la hižiese que él la avia de hazer alli o en otro cabo, porque su voluntad hera de no renunciar el dicho ofiçio e, ansý, el dicho Christóval Díaz antes de hazer la dicha renunçiaçión publicaba e dezía e después que la obo hecho que la hazía e hizo contra toda su voluntad e que se avía de yr a quexar dello a su Magestad (Alonso de Medina, preg. 18).

Estos hechos anuncian la actitud posterior de Díaz. Y es que, como señalan algunos testigos, sienpre tuvo propósyto de se yr a quexar ante sus Magestades por el agravio e fuerça que se le hazía $a^{57}$. De tal suerte que, una vez "liberado", el 3 de abril comparecía ante el alcalde ordinario

\footnotetext{
${ }^{50}$ Diego Sánchez, escribano del número y vecino de Cádiz, preg. 27.

51 Alonso de Medina, preg. 15.

52 Interrogatorio Ramírez, preg. 4.

${ }^{53}$ Interrogatorio Díaz, preg. 15.

54 Diego Sánchez, escribano del número y vecino de Cádiz, preg. 18.

55 Apéndice doc $\mathrm{n}^{\circ} 3$.

${ }^{56}$ Diego Sánchez, escribano del número y vecino de Cádiz, preg. 18.

${ }^{57}$ Francisco García, vecino de Cádiz, estante en Puerto Real, preg. 6, AGS, CRC, 87, 7-II, sf.
} 
de Puerto Real, Cristóbal López, y presentaba un requerimiento, instándole a hacer una probanza e información con la cual, entre otros, habría de seguir el pleito contra Ramírez en el Consejo Real ${ }^{58}$. En 7 de abril, desde Sevilla, escribía una carta misiva a sus hermanos en virtud de la cual al tiempo que les aclaraba sus intenciones, hazer algund daño si pudiese a Diego Ramírezpues tanto procuró de hazernos, y buscaba su aprobación, les informaba de los progresos de sus negociaciones en el Consejo y demandaba dinero para hacer frente a los gastos ${ }^{59}$. Al respecto, sorprende que la carta estuviera en poder de Ramírez y fuera incorporada por este al proceso, y, no menos, la facilidad de acceso y comunicación con los consejeros, en especial con Villanueva, para el cual, manifestaba Díaz, tengo justiçia e que él fará la petiçión e que me ayuda mucho ser menor porque no pude renunçiar el derecho que tenía en mi favor ${ }^{60}$. Díaz, por tanto, además, era menor de edad, circunstancia aquí esgrimida como eximente por el consejero y omitida en las recusaciones de Ramírez, mientras que para su hermano, el notario Diego González, fuera alegada, entre otras razones, por los cabildantes y los testigos de la ciudad para impedir su entrada en ejercicio ${ }^{61}$.

Por otra parte, el discurso de Ramírez y de sus testigos hace hincapié, especialmente, en el tema religioso, en su aptitud técnica y en la ausencia de coacción a la hora de otorgar Díaz la definitiva renuncia en su favor.

Coinciden los testigos en subrayar la condición de cristianos nuevos de Díaz y sus hermanos. Los de mayor edad declaran que sus padres vinieron a Cádiz, los más no saben si como judíos o ya conversos, y que el padre puso en la ciudad una tendezuela de agujas y alfileres. Al morir, su viuda, madre de los encartados, casó en segundas nupcias con un pintor cristiano nuevo, al cual quemaron los inquisidores en Vejer por judaizante. En su alocución antisemita, aparte de denunciar ciertas prácticas de dudosa moralidad en González ${ }^{62}$, inciden en la volubilidad aparente de sus creencias y, en consecuencia, en su falso cristianismo al afirmar que buen número de los de su credo que vivían en la localidad zarparon una noche en la "carabela Judía" para Lisboa ${ }^{63}$ desembarcando después en Berbería donde se volverían a convertir en judíos. Entre tales conversos citan a Cristóbal Díaz, hijo de Beatriz Núñez y

\footnotetext{
58 Apéndice doc $n^{\circ} 4$.

59 Apéndice doc $\mathrm{n}^{\circ} 5$.

${ }^{60}$ Idem.

${ }^{61}$ ROJAS VACA, María Dolores, "Los escribanos públicos”, op. cit., pp. 6, 11-12.

${ }^{62}$ LÓPEZ BELTRÁN, María Teresa, "En los márgenes del matrimonio: transgresiones y estrategias de supervivencia en la sociedad bajomedieval castellana”, IGLESIA DUARTE, José Ignacio de la (coord.), La familia en la Edad Media: XI Semana de Estudios Medievales, 2001, pp. 349-386; CANDAU CHACÓN, María Luisa, "Entre lo permitido y lo ilícito: la vida afectiva en los Tiempos Modernos", Tiempos Modernos: Revista Electrónica de Historia Moderna, vol. 6, núm. 18, 2009, pp. 1-21.

${ }^{63}$ Beatriz Martínez, vecina de Cádiz, preg. 12 y Leonor Sánchez, viuda de Diego de Contreras, vecina de Cádiz, preg. 12 .
} 
primo del aspirante a notario que, habiendo ejercido de escribiente doce o trece años antes y tras tornarse judío, pasó a llamarse Samuel de Sornaga. Con él embarcaron, igualmente, su mujer e hijos, la Mirona e hijos, Méndez y su mujer, Antón Martín, sastre, y su mujer e hijos y ciertos hijos de Tomás Moreno ${ }^{64}$. Todos parece que terminaron en tierra de moros, en Berbería, y más concretamente en las poblaciones de Salé, Tetuán y Fez.

... es público y notorio que el dicho Christóval Díaz e Diego Gonçález. e Alonso de Medina son bijos de judio e por tales son avidos e tenidos e conossidos e comúnmente reputados por christianos nuevos y este testigo los tiene por christianos nuevos. E que a oýdo dez̧ir en la dicha çibdad de Cádiz a Françisco Rodríguez, corredor de lonja, e a otros vezinos de la dicha çibdad que a tienpo que el dicho padre, de los susodichos, quedó en Castilla por christiano nuevo, vino a Cádiz e puso vna tendezuela de agujas e alfileles ${ }^{65}$. Ele fue preguntado al dicho su padre que a qué venía e respondió que a conprar de los moros los burtos que fazen en la dicha çibdad (a?) los mercaderes e christianos viejos para mantener aquellos hijuelos que tenía. E que sabe que los dichos Christóval Díaz e sus hermanos //r. tienen en Berbería primos e parientes que, siendo christianos nuevos, podrá aver dož o treze años, que vna noche tomaron en la dicha çibdad de Cádiz una caravela que después fue de Luis de Perzenda, mercader genovés, que se llamava "la caravela Judia" porque en ella se fue vn primo hermano del dicho Christóval Díaz e sus bermanos christianos nuevos e otros parientes suyos, los quales se tornaron de christianos nuevos judios e oy en día están allá e biben como judios de señal e ansý se nonbran nonbres de judios. E que a este testigo le fue mostrado en la dicha çibdad de Cádir un conosçimiento que hera escrito de la letra de su primo, del dicho Christóval Díaz e sus hermanos, el qual hera escriviente, e a este testigo le fue mostrado sy conosçía aquella letra e mirando abaxo dezía: lo firma Samuel de Sornaga e le dixeron a este testigo: pues este es el primo de Christóval Díaz que hera escriviente y este testigo conosçió su letra porque siendo christiano escrivía e le avía visto. E demás dixo que muchos vezinos de la dicha çibdad de Cádiz están descomulgados porque saben que Diego Gonçález, hermano del dicho Christóval Díaz, se echó carnalmente con la muger del dotor Azevedo, que es hermana de su misma muger, en la qual, siendo bivda, el dicho Diego Gonçález. ovo vna hija e, ansymismo, tiene hijos en su misma muger, que es hermana de la susodicha, e que pues su primo se tornó judio que tal confiança tiene de él e que no se espera menos (Nuño de Cepeda, preg. 10).

... sabe que el dicho Christóval Díaz es hijo de christianos nuevos que fueron judjóos e que este testigo los vydo venir a esta çibdad de Cádiz quando sus padres a ella vinieron a byvir e quando a ella vinieron no sabe sy eran judjó o christianos. Y que quedando byvda la madre del dicho Christóval Díaz se casó segunda vez. con un pintor christiano nuevo, el qual quemaron los ynquisidores en la bylla de Bejer por judyo y este testigo lo vydo quemar. E que este testigo vydo byvir en esta çibdad a los contenidos en esta pregunta diziendo llamarse christianos e después los vydo en Bervería judios pero que no sabe sy son parientes del dicho Christóval Diaz o no (Bartolomé de Capilla, preg. 12).

De otro modo, sabemos que, con frecuencia, en distintas poblaciones andaluzas y, en general, castellanas los judeoconversos ejercieron como notarios ${ }^{66}$ aunque, en el siglo XVI,

${ }^{64}$ Ramírez, interrogatorio, preg. 12.

${ }^{65}$ Sic.

${ }^{66}$ A modo de ejemplo véanse, para Jerez, CARRASCO GARCÍA, Gonzalo, “Judeoconversos de Jerez y el obispado de Cádiz a fines del siglo XV”, En la España Medieval, 29, 2006, pp. 341-342 y para Sanlúcar de 
existiera la conciencia social de que los judios, principalmente, ambicionaban los cargos de escribano para hacer más vulnerable a la comunidad cristiana ${ }^{67}$. Según se infiere, y para no reforzar las actuaciones del linaje hebreo, dada la cualidad de élite de poder consustancial al notario ${ }^{68}$, rechazan que concurran a la vez los tres conversos en el desempeño del cargo de escribano. Estiman que tendrían un peso excesivo, lo que, en su caso, haría inclinar la balanza siempre de su lado pues vernía mucho perjuizio a los vezinos e justiçia e avn los otros escrinanos públicos desta çibdad porque a donde estos se acostasen ${ }^{69}$ se haría todo lo que ellos quisyesen ${ }^{70}$.

Por el contrario, omitiendo toda alusión a la condición de converso de Díaz, sus testigos, considerando la aptitud del mismo y porque cada ofiçio es distinto e apartado de por sý e ay otros quatro escriuanos del número en la dicha çibdad ${ }^{11}$, no ven inconveniente alguno en el ejercicio simultáneo como notarios de los tres hermanos, habida cuenta de los precedentes existentes

Barrameda y Sevilla, GIL FERNÁNDEZ, Juan, "Dos padrones de conversos en Sanlúcar de Barrameda", Excerpta philologica. Iosepho ludovico Pereira Iglesias Sacra, vols. 10-12, Cádiz, 2000-2002, pp. 485-515, 2003, pp. 27 28; PARDO RODRÍGUEZ, María Luisa, "Lo privado y lo público. Juan Álvarez de Alcalá, escribano del número de Sevilla (1500-1518)", VILLALBA PÉREZ, Enrique y TORNÉ VALLE, Emilio (eds.), El nervio de la república: el oficio de escribano en el Siglo de Oro, Madrid, 2010, p. 53; para Carmona, GONZÁLEZ JIMÉNEZ, Manuel, Carmona medieval, Sevilla, 2006, pp. 116-117 y RAMÍREZ BARRIOS, Julio Alberto, "El concejo de Carmona y el nombramiento de escribanos: conflictos con el poder regio”, PUEYO COLOMINA, Pilar (ed.), Lugares de escritura: la ciudad. XII Jornadas de la SECCTTHH, Zaragoza, 2015, pp. 305-308; para Granada, MORENO TRUJILLO, María Amparo, "Las actuaciones de la inquisición y los escribanos judeo conversos del entorno del conde de Tendilla”, HID, 37, 2010, pp. 181-210; QUEVEDO SÁNCHEZ, Francisco, Familias en movimiento. Los judeoconversos cordobeses y su proyección en el Reino de Granada (ss. XV-XVII), Granada, Universidad, Facultad de Filosofía y Letras, Departamento de Historia Medieval y Ciencias y Técnicas Historiográficas, 2015 (tesis doctoral), http://hdl.handle.net/10481/43675 [consulta: 06/05/2018]; para Córdoba, EXTREMERA EXTREMERA, Miguel Ángel, El notariado en la España Moderna. Los escribanos públicos de Córdoba (siglos XVIXIX), Córdoba, 2009; para Málaga, LÓPEZ BELTRÁN, María Teresa, "Perfil de un judeoconverso del Reino de Granada: El escribano Antón López de Toledo", Revista del Centro de Estudios Históricos de Granada y su Reino, 18, 2006, pp. 53-76; para Jaén, PORRAS ARBOLEDAS, Pedro Andrés, Comercio, banca y judeoconversos en Jaén, 1475-1540, Jaén, 2008; para Murcia, MARTÍNEZ CARRILLO, María de los Llanos, "Escribanos e inquisición en los finales del siglo XV murciano", MARSILLA DE PASCUAL, Francisco (ed.), Littera scripta in honorem Prof. Lope Pascual Martinez, Murcia, vol. 2, 2002, pp. 597-609. Una visión de conjunto puede verse en DOMÍNGUEZ ORTIZ, Antonio, La clase social de los conversos en Castilla en la Edad Moderna, Granada, 1991.

${ }^{67}$ CARRACEDO FALAGÁN, Carmen, "El escribano municipal según una información enviada al Consejo de Castilla el año 1626: requisitos legales para ejercer el oficio”, Boletin del instituto de estudios asturianos, 133, 1990, p. 63.

${ }^{68}$ COSTAMAGNA, Giorgio, Il notaio a Genova tra prestigio e potere, Roma, 1970; TAMBA, Giorgio, Una corporazione per il potere. Il notariato a Bologna in età comunale, Bolonia, 1998.

${ }^{69}$ Según el Diccionario de Autoridades, acostar equivale a "seguir el partido, dictámen o parecer de otro, ponerse a su lado y declarase parcial" en tanto que acostarse "vale lo mismo que acercarse o arrimarse a alguna cosa".

${ }^{70}$ Interrogatorio promovido por Inés de Pareja, Francisco Rodríguez, corredor de lonja, preg. 5.

${ }^{71}$ Díaz, interrogatorio, preg. 23; contestan a la preg. 23 en los mismos términos planteados: Francisco Vázquez, alcalde de la cárcel, vecino de Cádiz; Pedro Cabrón, regidor y vecino de Cádiz; Gerónimo de Quirós, corredor de lonja, vecino de Cádiz; Francisco García, hijo de don García de la Cerda, vecino de El Puerto de Santa María, estante en Cádiz; Alonso Montote, hijo de Juan Montote, vecino de Cádiz; Cristóbal Díaz, hijo de Jorge Díaz, vecino de Cádiz, primo de Cristóbal Díaz; Antonio de Urdiales, vecino de Cádiz; Amigo de Amar, vecino de Cádiz; Juan de la Barrera, hijo de Rodrigo de Jerez, vecino de El Puerto de Santa María, estante en Cádiz; Alonso Galíndez de Amar, vecino de Cádiz; bachiller Antón de Frías, vecino de Cádiz; Diego Sánchez de Cádiz, alcalde de la fortaleza y regidor de Cádiz; Jácome Justiniano, mercader de Egio, estante en Cádiz; Pedro Marrufo, regidor y vecino de Cádiz; Cristóbal Rafael, procurador y vecino de Cádiz; Diego Sánchez de Argumedo, regidor y vecino de Cádiz; Pedro Sánchez de Estopiñán, regidor y vecino de Cádiz; Francisco de Nava, sedero, vecino de Cádiz; Diego Sánchez Bernalte, regidor y vecino de Cádiz. 
dentro del colectivo de los regidores en Jerez de la Frontera y en Cádiz. Es el caso de los veinticuatros jerezanos, los hermanos Martín, Gerónimo y García de Ávila. Igualmente el de los regidores gaditanos Sancho Martínez de Cádiz y sus hijos, Simón Gentil y Diego Sánchez Martín nueve o diez años antes, también el de los dos hermanos Estopiñán ${ }^{72}$, el de Antón Bernal e hijo y, en fin, el de Cristóbal Marrazo y Pedro, su hijo. En algún ejemplo, no sólo se señala el servicio al unísono de un tipo concreto de oficio por miembros de una misma familia sino, además, el desempeño de otros varios oficios distintos que recaen en uno solo de sus miembros ${ }^{73}$. Así, Juan de Haya fue regidor y escribano del número a la vez y, al mismo tiempo que sus hijos, Martín de Haya, también regidor, y otro hijo, cuyo nombre no mencionan, quien sirvió como escribano del número y del cabildo. Jaime de Luna aparece en una ocasión como veinticuatro de Jerez y como regidor de Cádiz ${ }^{74}$, pluralidad de cargos en la misma ciudad o en poblaciones distintas habitual a principios del siglo $\mathrm{XV}^{75}$.

\begin{abstract}
... a paresçer deste testigo no es ynconveniente que el dicho Christóbal Díaz. sea escriuano del número concurriendo en él las calidades que dicho a este testigo avnque los dichos Diego Gonzálež e Alonso de Medina, sus hermanos, sean escriuanos, ansý mismo, del número desta dicha çibdad e que le paresçe que no es ynconveniente ser los dichos tres hermanos escriuanos del número por lo que dicho tiene e porque cada ofiçio es distinto e apartado por sý e porque sabe y es público e notorio que en esta dicha çibdad ay otros quatro escriuanos del número desta dicha çibdad. E que sabe que en esta dicha çibdad a avido vn padre e vn hijo regidores que heran Antón Vernal e su hijo e, ansý mismo, los Estopiñanes que heran dos hermanos ser regidores76 en vn tienpo e que, asý mismo, vio que Juan de Aya, vezino que fue desta dicha çibdad, hera regidor y escrinano del número desta dicha çibdad e vn hijo suyo que se llamaba Martín de Aya hera regidor e otro bijo del dicho Juan de Aya hera escriuano del número e del cabildo desta dicha çibdad y esto que los vio este testigo al dicho Juan de Aya e los dichos sus hijos tener en un tienpo los dichos ofiçios e servilles cada vno de ellos el suyo e que esto ansý es público e notorio en esta dicha çibdad de Cádiz. (Antonio de Urdiales, vecino de Cádiz, preg. 23).
\end{abstract}

... Le paresşe que, concurriendo en el dicho Christóval Díaz las calidades que dicho ha, no es ynconviniente ser todos tres hermanos escriuanos públicos desta dicha çibdad e porque cada ofiçio de los susodichos es distinto e apartado por sý eporque sabe que ay en esta dicha çibdad otros quatro escrinanos del numero. E que sabe que en la çibdad de Xerez de la Frontera ay tres hermanos que son veynte e quatros de ella, los quales son Martín de Ávila e Gerónimo de Ávila e Garçía de Ávila. E que sabe que puede aver syete o ocho años, poco más o menos tienpo, que en esta dicha çibdad fueron regidores en un tienpo Sancho Martin e Diego Sánchez de Cádiz e Gerónimo Gentil, hijos del dicho Sancho Martín, todos tres juntamente, padre e bijos, e que lo sabe este testigo porque lo vio e ansý es público e notorio (Alonso Galíndez de Amar, vecino de Cádiz, preg. 23)77.

\footnotetext{
72 Tachado: çibidos

73 TOMÁS Y VALIENTE, Francisco, "Origen bajomedieval de la patrimonialización y la enajenación de los oficios públicos en Castilla", Actas del I Symposium de Historia de la Administración, Madrid, 1970, pp. 150-151.

${ }^{74}$ Así en el requerimiento que practica ante el corregidor, fechado en 11 de marzo, AGS, CRC, 628, 12, sf.

75 Idem.

76 Tachado: çibidos

77 Para Cádiz y Jerez véase, asimismo, Diego Sánchez de Cádiz, alcaide de la fortaleza y regidor de Cádiz, preg. 23; Pedro Sánchez de Estopiñán, vecino y regidor de Cádiz, preg. 23; Alonso Galíndez de Amar, vecino de Cádiz, preg. 23; Francisco de Nava, sedero, vecino de Cádiz, preg. 23.
} 
... que a visto que en esta dicha çibdad que abrá tres años, poco más o menos tienpo, heran regidores desta çibdad Christóval Marraso e su hijo, Pero Marraso (Cristóbal Rafael, vecino y procurador de Cádiz, preg. 23) ${ }^{78}$.

Esta circunstancia, por otro lado, pone de manifiesto la presencia de sagas familiares especialmente en el grupo de los regidores gaditanos y jerezanos, como era usual, asimismo, en otros lugares ${ }^{79}$. Podemos decir, por consiguiente, que los lazos familiares unen a estas élites de poder.

Al respecto de su aptitud técnica, los testigos destacan la habilidad y suficiencia de Ramírez por quien muestran preferencia por ser honbre antiguo en el ofiçio y más esperimentado ${ }^{80}$. El testigo Nuño de Cepeda resalta la diligencia con que acomete la registración puesto que, avnque tal como hoy pasen ante él veynte o çinqüenta escrituras, quando amaneçe ninguna está por registrar, y la pericia manifiesta por lo que ha visto en sus viajes allí por donde circulan sus escrituras (Cádiz, Jerez, Sanlúcar, Sevilla, Canarias, Valencia, Toledo, París, Roma y Nápoles), calificándolo de muy gentil escrivano de péndola. Opina que es querido y considerado en Cádiz y su comarca, con muy buena fama entre los comerciantes por ser de habilidad superior a la del resto de sus compañeros. Concluyendo con las alabanzas, como señala otro testigo, a visto que ba vuelto sus derechos a personas neçesitadas ${ }^{81}$, algo que era de obligado cumplimiento entre los notarios malagueños pues no debían llevar derechos a los pobres ${ }^{82} \mathrm{y}$, para el ámbito judicial, en los cordobeses ${ }^{83}$, según recogen sus ordenanzas municipales desde la época de los Reyes Católicos ${ }^{84}$. Por todo lo cual estiman que sería más serviçio de Dios e de su Magestad e bien público desta çibdad que el dicho Diego Ramirez tenga el dicho ofiçio de escrinano público antes que el dicho Christóval Diaz ${ }^{85}$.

\footnotetext{
78 Para Cádiz, véase, asimismo, Amigo de Amar, vecino de Cádiz, preg. 23; para Jerez, Jácome Justinián, mercader de Egio, estante en Cádiz, preg. 23; Diego Sánchez de Argumedo, regidor y vecino de Cádiz, preg. 23. ${ }^{79}$ A modo de ejemplo véanse TOMÁS Y VALIENTE, Francisco, op. cit., pp. 141-143; "La venta de oficios de regidores y la formación de oligarquías urbanas en Castilla (siglos XVII y XVIII)”, HID, 2, 1975, pp. 533-535; HERNÁNDEZ BENÍTEZ, Mauro, "Y después de la ventas de oficios ¿qué? (Transmisiones privadas de regimientos en el Madrid Moderno, 1606-1808)", Anuario de Historia del Derecho Español, 65, Madrid, 1995, pp. 722-724, 730-41.

80 Juan Díaz, vecino de Cádiz, preg. 10.

${ }^{81}$ Francisco Fernández Duque, barbero, preg. 10.

82 ARROYAL ESPIGARES, Pedro Juan; MARTÍN PALMA, María Teresa; CRUCES BLANCO, María Ester, Las escribanias públicas de Málaga (1487-1516), Málaga, 1991, p. 68.

83 OSTOS SALCEDO, Pilar, "Aranceles notariales de Córdoba (1482-1495)", HID, 25, Sevilla, 1998, pp. 521522.

${ }^{84}$ Esta disposición no la recogen, para la misma época, los aranceles notariales de Sevilla ni de Jerez de la Frontera, cfr. PARDO RODRÍGUEZ, María Luisa, "Aranceles de escribanos públicos de Sevilla", HID, 25, Sevilla, 1998, pp. 525-536; ROJAS VACA, María Dolores, "Notariado público y documento notarial en Jerez de la Frontera en el tránsito a la modernidad", OSTOS SALCEDO, Pilar y PARDO RODRÍGUEZ, María Luisa (eds.), El Notariado andaluz en el tránsito de la Edad Media a la Edad Moderna. I Jornadas sobre el Notariado en Andalucia, Sevilla, 1995, pp. 308-310.

${ }^{85}$ Francisco Fernández Duque, barbero, preg. 10.
} 
... la sabe... porque de el dicho tienpo contenido en la dicha pregunta el dicho Diego Ramírez de la Rúa a vsado, y este testigo le a visto, vsar el dicho ofiçio de escrinano público muy bien e fiel e diligentemente porque es público e notorio en Cádizy en Seuilla y en Xerezy en Sanlúcary en Canaria y en Valencia y en Granada y en Toledo e fasta París donde sus escripturas del dicho Diego Ramírez. an ydo que este testigo a visto y, ansymismo, en Roma y en Nápoles y en otras muchas partidas ${ }^{86}$ que el dicho Diego Ramírez es más ábil en su ofiçio que otro ninguno y este testigo en algunas de las dichas partes que a estado y en las avdiençias de Granada y en Semilla y en el conçejo no a visto otro que más ábil que él sea porque en su ofiçio tiene estas eçelençias muy gentil escriuano de péndola, muy liberal, muy ábil en lo público e criminal / / v. y en todo lo demás tiene otra eçelençia entre todos los escriuanos del reyno que avnque tal como oy pasen ante él veynte o çinqüenta escripturas quando amanesçe ninguna está por registrar. Es por su persona honbre muy bien quisto ${ }^{87}$ en toda la çibdad de Cádiz e comarcas de ella le quieren bien y entre todos los mercaderes de la dicha çibdad de Cádiz es avido por más ábily lo es que ninguno de sus conpañeros escriuanos públicos de la dicha çibdad de Cádiz. E si el dicho Christóval Diaz fuese escriuano, syendo tres hermanos que son christianos nuevos, fazerse ý a lo que ellos quisiesen avnque pesase a los otros christianos viejos (Nuño de Cepeda, preg. 8).

El contrapunto a tales excelencias lo ponen los testigos de Díaz que vieron a Ramírez desatender el oficio y la clientela para abandonarse al juego, cobrar derechos excesivos ${ }^{88}$, e incurrir en algún que otro delito:

... a visto quexarse a muchas personas en esta çibdad del dicho Diego Ramírez que les llieva derechos demasyados de las escrituras e avtos que ante él pasan como escriuano e, asý mismo, a oýdo dezir que a vn Juan Batista, vezino desta çibdad, pescador, llevó por sacar vna escriptura que avía pasado ante vn anteçesor del dicho Diego Ramírez del dicho ofiçio diez ducados de oro <no> meresçiendo vn ducado y esto que lo a oýdo dezir este testigo a muchas personas públicamente en esta çibdad (Francisco García, hijo de don García de la Cerda, vecino de El Puerto de Santa María, estante en Cádiz, preg. 21).

... a visto este testigo que muchos vezinos desta dich a çibdad / /v. se an quexado de él porque les lleva derechos demasyados de los que a de aver e que a vn Juan Batista, pescador, vezino desta dicha çibdad, llevó diez ducados por buscar vna escriptura y esto que lo save este dicho testigo porque lo a oýdo a muchas personas públicamente e porque a visto quexarse al dicho Juan Batista del dicho Diego Ramírez. de lo susodicho (Cristóbal Díaz, hijo de Jorge Díaz, vecino de Cádiz, primo-hermano, preg. 21).

... cree este testigo que el dicho Diego Ramírez e otros escribanos desta çibdad y avn de fuera della a las vezes cobran más derechos de los que les pertenesçen (Hernán Gascón, escribano del cabildo, vecino de Cádiz, preg. 29).

... a oýdo quexarse del dicho Diego Ramírez que llevava derechos demasyados y exçesybos espeçialmente en sacar escripturas de registros de Juan de Aya en cuyo ofiçio el dicho Diego Ramírez subçedió (Diego Sánchez, escribano público del número y vecino de Cádiz, preg. 29) 89.

86 Sic.

${ }^{87}$ Según el Diccionario de Autoridades, quisto equivale a "querido, apreciado y estimado".

${ }^{88}$ Diego Sánchez Bernalte, vecino y regidor de Cádiz, preg. 29, señala que lleva derechos demasiados.

${ }^{89}$ No contempla el arancel general de los Reyes Católicos el cobro de derechos por búsqueda, cfr. NR Lib 4, T 
... dixo este testigo... que el dicho Christónal Diaz es persona ábil e sufiçiente para el dicho ofiçio de escriuano público desta dicha çibdad e de confiança e crédito e que lo sabe porque le a tratado e conversado tienpo acá que dicho tiene que le conosçe e por tal le tiene este testigo e vee que le tienen en esta dicha çibdad e que sabe que el dicho Christónal Diaz es onbre de buena fama e trato e conversaçión e de mucha limpieça e que esto que lo sabe este testigo por lo que dicho tiene en esta pregunta e que al paresçer deste testigo conviene más al serviçio de sus Magestades e al bien desta dicha çibdad que el dicho Christónal Diaz, tenga el dicho ofiçio sobre que es este pleito antes que el dicho Diego Ramírezy esto que le paresçe a este testigo por lo que dicho tiene en esta pregunta e porque vna dueña desta çibdad que se dize Guiomar / /v. que fue de Juan Ramos, vezino desta çibdad, ya defunto, se quexó del dicho Diego Ramírez que havía pasado ante él vna escritura de vn tributo de sobre las casas de vn Gaspar (Garçias?), vezino desta dich a çibdad, el qual dicho tributo se avía de dar a la dicha Guiomar Gonçález. e les dezía que al tienpo que se otorgó la dicha escritura que ella no avía estado presente e que el dicho Diego Ramirez en la dicha escritura dezía que sý e que esto que lo sabe este testigo porque lo oyó dezir a la dicha Guiomar Gonçález e a otras muchas personas desta dicha çibdad públicamente (Alonso Galíndez de Amar, vecino de Cádiz, preg. 21).

... sabe que el dicho Christóval Diaz es persona ábile e sufiçiente para el dicho ofiçio e que sabe que el dicho Christóval Diaz es de más crédito e confiança que no Diego Ramírez e que esto que lo sabe porque este testigo a conversado e contratado con el dicho Christóval Diaz e con el dicho Diego Ramírez e conosçe al uno e al otro e por tal, como dicho tiene, vee e a visto que tienen al dicho Christóval Diaz. en esta çibdad los vezinos della e porque vna carta exsecutoria de los señores presydente e oydores de la Chancillería de Granada que tenía vn Diego Marroquin, vezino desta dicha çibdad, contra vnos so <bri>nos deste testigo, cuyo tutor hera este testigo, que la presentaron ante el dicho Diego Ramírez.e por ella mandavan los señores presydente e oydores que fuese notificada a este testigo, como tutor de los dichos sus sobrinos, antes que por ella exsecutasen e syn que a este testigo fuese notificada la dicha carta exsecutoria el dicho Diego Ramírez dio fee como me la avía notificado e avn puso por testigos dos criados suyos. E que por esto le paresçe a este testigo e save que el dicho Christóval Diaz es de más crédito e confiança que no el dicho Diego Ramírez. E que sabe que el dicho Christóval Diaz es honbre de buena fama e trato e conversaçión y de much a limpieza e que esto que lo sabe por trato y conversaçión que este testigo tiene con el dicho Christóval Diaz e porque asi es público e notorio en esta dicha çibdad entre los vezinos e moradores della e que sabe, por lo que dicho tiene, que conviene más al serviçio de su Magestad e al bien desta dicha çibdad que el dicho Christóval Diaz tenga el dicho ofiço de escriuanía antes que no el dicho Diego Ramírez e que esto ansý es público e notorio (Antonio de Urdiales, vecino de Cádiz, preg. 21).

... cree este testigo que el dicho Christóval Diaz es de mejor confiança e crédito que no el dicho Diego Ramirezporque en çierto pleyto que este testigo tratava con un nieto deste testigo ante el dicho Diego Ramírez ovieron de comprometerlo e poner por juezes árbitros al liçençiado Pérez e al bachiller Frías, vezinos desta dicha çibdad, e al liçençiado Verdugo, que hera alcalde en esta dicha çibdad a la sazón, e que en el compromiso que sobre ello se hizo, que se hizo ante el dicho Diego Ramírez, fue para que los dichos juezes, todos tres, lo viesen e sentençiasen juntamente e no el vno sin el otro e que el dicho

27. Sí que lo hacen los aranceles locales de Sevilla, PARDO RODRÍGUEZ, María Luisa, "Aranceles de escribanos", op. cit, p. 532 y de Jerez de la Frontera (1484, 1490), ROJAS VACA, María Dolores, "Notariado público y documento", op. cit., p. 309, estipulándolo en dos y cuatro maravedíes por año de antigüedad de la escritura sacada, respectivamente. Mientras, se prohíbe la percepción de tales derechos, expresamente, en Málaga, ARROYAL ESPIGARES, Pedro Juan; MARTÍN PALMA, María Teresa; CRUCES BLANCO, María Ester, op. cit., p. 68, en tanto que el arancel de Córdoba nada menciona, OSTOS SALCEDO, Pilar, op. cit., pp. 503-524. 
compromiso, aviéndose otorgado como dicho tiene, estava que el liçenciado Pérezy el bachiller Frías lo sentençiasen como lo sentençiaron e que si los dichos liçençiado Pérezy el bachiller Frías no se conçertasen en el sentençiar que se diese parte dello al dicho liçençiado Verdugo para que él como terçero lo viese y fuese en sentençiar el dicho pleyto. E que este testigo le paresçe que el dicho compromiso no se otorgó sino de manera que el liçençiado Pérezy el bachiller Frías en ninguna manera pudiesen sentençiar syn el dicho liçençiado Verdugo como sentençiaron e que ansý les paresçió a muchas personas que presentes se hallaron al otorgar del dicho compromiso. E que por esto cree que el dicho Christóval Diaz es de mejor confiança e crédito que no el dicho Diego Ramírez. E porque en vn pleyto que ha traj́do ante el dicho Diego Ramirez un Vizconte Lucián, vezino desta dicha çibdad, le a vis-//v. to quexarse del dicho Diego Ramírez que vna provança que ante él hizo el dicho Diego Ramírez. no puso en algunos dichos de los testigos lo que los testigos declaravan (Pedro de Medina, vecino de Cádiz, preg. 21).

De otro lado, Ramírez rebate las denuncias de extorsión sobre la base de tres acontecimientos. El acuerdo complaciente con el predicador Estopiñán, el hecho de haber acudido voluntariamente y solos los tres hermanos a otorgar la renuncia y, finalmente, más contundente, la satisfacción manifiesta por la devolución del precio pagado por el oficio, además de las costas o interés derivado.

En efecto, frente a su adversario, Ramírez y sus testigos, negado cualquier tipo de coacción antes, durante y después del acto de otorgamiento de la renuncia, subrayan la mediación previa de Estopiñán con los hermanos de Díaz, a instancia del suegro y esposa de Ramírez, y la complacencia de aquéllos en aras de agradar al referido licenciado ${ }^{90}$ que pretendía remediar el estado de la familia y, especialmente, de la mujer quien a cabsa dello estava mal con su marido:

... sabe que a cabsa que se dería en esta çibdad de Cádiz que el dicho Diego Ramírez avía renunçiado su ofiçio de escriuano público en el dicho Christóval Díaz, su muger del dicho Diego Ramírez, reçibió mucha pena de ello porque le vydo la cara arañada e llorando e que a cabsa dello estava mal con su marido. E, asý mismo, vydo que el liçençiado Estopiñán, predicador, rogó al dicho Christóval Díaz.e a Diego Gonçález. e Alonso de Medina, sus hermanos, que ovyesen por byen de bolver su fiçio al dicho Diego Ramirez, los quales lo ovyeron por bien con que se le pagase su prinçipal e las costas que avian fecho (Pedro Gil, estante en Cádiz, preg. 2).

... sabe que, no estando en esta çibdad el dicho Christóval Díaz, se supo en ella cómo el dicho Dyego Ramirez le avia renunçiado su ofiçio de escrivanía pública con la qual era ydo el dicho Christóval Díaz. a la corte. A cabsa de lo susodicho vydo este testigo andar muy penado a su suegro del dicho Diego Ramirez e por el dicho tienpo oyó dezir que su muger del dicho Diego Ramírez a cabsa de aver sabido de la renunçiaçión se quería aborcar e se avja mesado. E venido que fue a esta çibdad el dicho Christóval Díaz, dezian que traýa el título. Vydo este testigo que el lyçençiado Estopiñán habló con Diego Gonçález e Alonso de Medina, escriuanos públicos, hermanos de Christóval Díaz, los quales dichos Dyego Gonçález. e Alonso de Medina dixeron a este testigo que el dicho lyscençiado Estopiñán, de parte del dicho Diego Ramýrezy de su suegro e muger, les avían rogado reçibyesen sus dineros y bolbyesen su

\footnotetext{
${ }^{90}$ Francisco Camacho, hijo de Bartolomé Suárez, difunto, vecino de Cádiz, preg. 2.
} 
ofiçio al dicho Diego Ramírez e que asý lo avian fecho y que el dicho Christóval Díaz, su hermano, se lo avía tornado a renunçiar, lo qual le pareçe a este testigo que pasó en un día de la semana santa pasada (Diego Ramírez, procurador de causas, vecino de Cádiz, preg. 2).

... sabe que vn dia de la Semana Santa o býspera de Ramos pasada, estando este testigo en la yglesia de Santa Cruz desta dicha çibdad de Cádiv, llegó alli el lyscençiado Estopinãán e dixo que se viniese con él a la plaça e se vino e se juntó en el ospital de la Misericordia con Diego Gonçález. e Alonso de Medina, escriuanos públicos, a los quales rogó oviesen por bien de hazer que Christóval Diaz, su hermano, bolviese su ofiçio de escrivanía pública al dicho Dyego Ramirez, bolvyéndole sus dineros e pagándoles sus costas, los quales dixeron que por hazer plazer al dicho lycençiado Estopiñán avian por bien de lo hazer con que se les pagase las costas moderadamente e asý lo acordaron de su voluntad y este testigo lo vydo e se halló presente y luego que pasó esto el dicho lysençiado lo dio por respuesta al dicho Diego Ramirez e su suegro (Francisco Camacho, hijo de Bartolomé Suárez, difunto, vecino de Cádiz, preg. 2).

Pero no cabe duda que si algo influyó en la decisión tomada por Díaz y sus hermanos de otorgar la renuncia a favor de Ramírez, al margen de haz̧er plazer al dicho liçençiado Estopiñán ${ }^{91}$ y de tirarse de embaraços y poner a riesgo lo que no tenía, fue la contrapartida de la devolución del precio pagado más las costas o gastos derivados de la transmisión y expedición del título pues avían avido por bien de resşebir el prinçipal que avian dado al dicho Diego Ramírez. e çinqüienta ducados por las costas e avían fecho con Christóval Diaz, su hermano, avnque con mucho travajo, que renunçiase el dicho ofiçio en el dicho Diego Ramírezy que con él le ayudase Dios que a su bermano no le faltaría ofiçio en otra parte y más honroso e con menos dineros ${ }^{22}$. En fin, un ágape o colaçión en casa de Luna, del que fueron partícipes todas las partes implicadas, cerraba y sellaba la transacción o acuerdo privado $^{93}$.

... dixo que lo que sabe es que este testigo vido que Diego Gonçález. e Alonso de Medina, escrinanos públicos, e Christóval Díaz, su hermano, reçebieron quinientos e tantos ducados del dicho Diego Ramirez e este testigo les dyo por el dicho Diego Ramírez a los sobredichos obra de quatrocientos ducados, poco más o menos, e el resto a cunplimiento de lo que avian de aver les pagó Jaime de Luna, regidor, en vna çédula para Sevilla que los prestó al dicho Diego Ramírez en la dicha cédula, los quales ducados reçebieron los susodichos por raz̧ón que el dicho Christóval Díaz avía buelto a renunçiar el ofiçio de escrivanía en el dicho Diego Ramírez e el dicho Diego Ramírez. les bolvía los dichos ducados e asý pasó en casa del dicho Jaime de Luna (Miguel Mora, mercader, estante en Cádiz).

... dixo que lo que sabe es que vio que dentro en la Iglesia de la Misericordia desta çibdad se conçertaron los dichos. Alonso de Medina e Diego Goncález. e Christóval Díaz, su hermano, con el dicho Diego Ramírez de la Rúapara que el dicho Christóval Diaz bolviese a renunçiar el ofiçio de la dicha escrivanía al dicho Diego Ramireze él le bolviese los quinientos e setenta e sinco ducados que dellos avía resçebido

\footnotetext{
91 Idem.

92 Diego Sánchez, escribano del número y vecino de Cádiz, preg. 27.

${ }^{3}$ Nuño de Cepeda, preg. 5; Pedro Lorenzo, vecino de Cádiz, compadre de Diego Ramírez, preg. 5; Francisco Rodríguez, corredor de lonja, vecino de Cádiz, preg. 4.
} 
con mas çinqüienta ducados de costas. E con este acuerdo e conçierto se vinieron a casa de Jaime de Luna, regidor desta dicha çibdad. Antes que llegasen vido este testigo çiertos dineros aparejados para les dar que heran los que dicho tiene e obra de treynta mill maravedies, poco más o menos, para cunplimiento a los dichos quinientos e setenta e çinco ducados del prinçipal e çinqüenta ducados de costas en vna çédula para Sevilla. E vido este testigo todos los dichos Diego Gonçález. e Alonso de Medina y Christóval Diazjuntos e contentos e satisfechos de los dichos ducados e quedaron conformes e pagados con ellos e se fueron de casa. E esto sabe porque lo vido e estava presente (Jaime de Luna, el mozo, vecino de Cádiz).

$\mathrm{Al}$ respecto del pago del precio debemos destacar la intervención activa de Luna ya que aportó un resto para cumplimentar el principal y los 50 ducados de costas, que hizo efectivos en una çédula o letra a su propio cargo sobre Sevilla, y que no harían sino acrecentar la deuda del escribano.

Con motivo de los préstamos que concedía, aparte de lucrarse, Luna compraba las voluntades de los prestatarios y, entre ellos, la de nuestro notario. Al tiempo tejía una red de relaciones clientelares que, basadas en el binomio "lealtad y servicio versus favores y protección”, respondían al propósito de afianzar su potestad en la localidad ${ }^{94}$. De otro lado, soborno y abuso de autoridad parecen algo cotidiano en la sociedad gaditana del momento, aquí ejemplificados en la persona de un regidor cuyo poder económico, al margen del político, sólo tenía parangón en la fortuna amasada por el mercader de Egio, estante en la localidad, Jácome Justinián, tan ryco como él e tan poderoso en esta çibdad ${ }^{55}$.

... dixo que sabe que el dicho Jayme de Luna es el más rico e poderoso de todos quantos ay en esta dicha çibdad e que lo sabe porque ansý es público e notorio e que sabe que hes sabio e mañoso e que todo lo que él quiere hazer e haze en esta dicha çibdad e lo guía por do él quiere e que esto que lo sabe este testigo por ser tan ryco como él e tan poderoso en esta çibdad (Jácome Justinián, mercader de Egio, estante en Cádiz, preg. 4).

Díaz permaneció en la ciudad hasta el fin de la Pascua de Resurrección. Dado que falta su nombre en la relación de escribanos del número posteriores de Cádiz ${ }^{96}$, cabe suponer que terminase ejerciendo de notario en otra población, conforme auguraban Medina y González para quienes, con cierta arrogancia, según vimos, a su hermano no le faltaría ofiçio en otra parte y más honroso e con menos dineros ${ }^{97}$.

\footnotetext{
94 Sobre redes clientelares véanse, por ejemplo, MARTÍNEZ MILLÁN, José, "Las investigaciones sobre patronazgo y clientelismo en la administración de la Monarquía Hispana durante la Edad Moderna", Studia Historica. Historia Moderna, vol 15, 1996, pp. 83-106; FELANI PINTOS, Alberto Juan, "Las relaciones de patronazgo y clientelismo en la Monarquía Hispánica: un estado de la cuestión", Tiempos Modernos: revista electrónica de Historia Moderna, 38, vol 9, 2019/1, pp. 58-83.

${ }^{95}$ Cfr., igualmente, Pedro Cabrón, regidor y vecino de Cádiz, preg. 21.

96 Idem.

${ }^{97}$ Diego Sánchez, escribano público, preg. 27, recogiendo las palabras de los hermanos de Cristóbal Díaz. En
} 
... después de fecha la dicha renusçiaçión estovo e andwvo por la dicha çibdad de Cádi fasta el fin de Pascua Florida e a todos los que le preguntavan mostrava alegre voluntad e dezía que holgava de aver buelto a renusçiar el dicho ofiçio porque ya él tenía sus dineros e que oviese el dicho Diego Ramírez el dicho ofiçio pues hera suyo (Nuño de Cepeda, preg. 7).

Por el contrario, sabemos que Ramírez siguió desarrollando su actividad notarial en Cádiz, pues en 1535, a la edad de 45 años, figura testificando en un juicio de residencia practicado para evaluar la gestión del corregidor gaditano saliente Francisco Cherino ${ }^{98}$.

\subsection{Desenlace}

Tras las alegaciones formuladas por ambas partes ${ }^{99}$ y las oportunas probanzas, hemos de esperar a comienzos de septiembre para conocer el desenlace del litigio. En efecto. El 6 de septiembre, Cristóbal Díaz, en calidad de escribano de los reinos, elevaba súplica al monarca. Por ella se apartaba del pleito sostenido con de la Rúa sobre la escribanía en cuestión, abandonando así toda pretensión al respecto, y solicitaba la confirmación de la merced regia del oficio en beneficio de Ramírez ${ }^{100}$. La petición recibía el fiat el día $10^{101}$, mientras el Consejo Real expedía la pertinente provisión o título del oficio en su favor el 13 del mismo mes ${ }^{102}$.

Llama la atención, tanto en el pleito de 1515 como en este, la aparente tolerancia con la cual el Consejo Real "obvia" la ley y las consecuencias punibles de su incumplimiento. La actitud adoptada por el Ayuntamiento es distinta pues el cabildo local mayoritariamente, en $1515^{103}$, y, a través de un regidor, en 1526, advierte de la ilegalidad cometida en el modo de transmisión de la escribanía y conmina al corregidor y al alcalde a tomar las medidas oportunas.

Y es que en el proceso de 1526 sólo en una ocasión se menciona que, por efecto de la compraventa, el oficio está perdido y, como tal, queda vacante y a disposición del monarca para su ulterior provisión, amén de confiscado el precio en beneficio de la hacienda regia. Así el 11 de marzo, Jaime de Luna, veinticuatro de Jerez y regidor de Cádiz, presentaba al corregidor, Fernán Pérez de Torres, y a su alcalde mayor, el licenciado Téllez, un

\footnotetext{
la misma línea refiere lo oído Jaime de Luna, veinticuatro de Jerez y regidor y vecino de Cádiz, preg. 7 y Francisco Fernández Duque, barbero, preg. 7.

98 AGS, CRC, 246, 3.

${ }^{99}$ Apéndice docs $n^{\circ}$ s 6, 7 y 8.

100 Apéndice doc $\mathrm{n}^{\mathrm{o}} 10$.

101 Idem, en nota marginal.

102 ROJAS VACA, María Dolores, "Los escribanos públicos”, op. cit., anexo, p. 346.

103 Ibidem.
} 
requerimiento en virtud del cual, habida cuenta de la constancia de la venta del oficio y de la ida de Díaz al Consejo Real con la renuncia para hacerla pasar con falsa relaçión e porque, según las leyes e premáticas destos reynos e capitulo de Cortes, el dicho ofiçio es perdido e es a proveer a su Magestad a otras personas, les instaba a que si por caso el dicho Christóval Díaz viniere con la dicha provisyón de la dicha escriuanía que no lo reçiban antes la pronusçien por perdida reservándola para su Magestad e que della faga merçed a quien fuere seruido. El alcalde mayor, atento al mandato regio, constándole la venta,

\begin{abstract}
declarava e declaró el dicho ofiçio porperdido e los maravedies que por ellos se dieron e los mandó aplicar para la cámara e fisco de su Magestad, conforme a las dichas leyes e premáticas e capitulos. E para ello mando a Pero de Cárdena, alguazil mayor desta çibdad, que saque los maravedies de poder del dicho Diego Ramírez e los trayga ante él para que sean dados al reçeptor de las penas de cámara para que los tenga fasta tanto que su Magestad mande lo que se faga dello. E desde agora mando al dicho Christóval Díaz. que no vse del dicho ofiçio fasta tanto que su Magestad lo provea ${ }^{104}$.
\end{abstract}

Pero ni los interesados ni los testigos se hacen eco de esta medida. Lo chocante del tema es que la recusación parte del benefactor de Ramírez quien debía tener muy claro que, incluso perdido el oficio y el precio, la nueva provisión regia había de recaer en su inicial poseedor de forma que, no habiendo recepción de Díaz, se facilitaba el camino.

Ciertamente, al tiempo que se incumple la norma se permite que Ramírez continúe ejerciendo el oficio. Cabría preguntarse: ¿hubo algún tipo de dispensa? y, si la hubo, ¿̇a cuánto ascendió el servicio y quién lo pagó? Los interrogantes quedan por el momento abiertos.

\title{
2. A modo de conclusión: El notariado público de Cádiz en la primera mitad del siglo
} XVI

En 1526 los oficios notariales gaditanos se mantienen en el número existente en $1515^{105}$. Los notarios ejercientes son siete: Fernán Sánchez, Lope de Medina, Diego Ramírez de la Rúa, Diego Sánchez, Diego González, Alonso de Medina y Manuel Ferraz. Todos alcanzan el cargo previa renuncia del antecesor, mecanismo que se configura como la vía oficial por excelencia de acceso a tales oficios ${ }^{106}$. De los 26 ejemplos considerados entre 1502

\footnotetext{
104 CRC, 628, 12.

105 Todas las indicaciones relativas a aspectos del pleito gaditano Cádiz-Diego González de 1514-1515, en delante de 1515, proceden de ROJAS VACA, María Dolores, “Los escribanos públicos”, op. cit.

106 Sobre los orígenes y significado de la renuncia y el devenir posterior de las mismas para Castilla, sin circunscribirlas a oficios concretos, véanse TOMÁS Y VALIENTE, Francisco, "Origen bajomedieval”, op. cit., pp. 125-139; "Ventas de oficios públicos en Castilla durante los siglos XVII y XVIII”, Gobierno e instituciones en la España del Antiguo Régimen, Madrid, 1982, pp. 151-177. Trata de nuevo el tema para Indias en TOMÁS Y VALIENTE, Francisco, La venta de oficios en Indias (1492-1606), 1982, Madrid, pp. 35-139 y, especialmente, referido a los oficios de escribanías en TOMÁS Y VALIENTE, Francisco, "La venta de oficios en Indias y en
} 
y 1542, la vacante por fallecimiento está presente exclusivamente en 1537 cuando al morir Diego Sánchez le sucede Diego Pérez de Lequeito ${ }^{107}$. Hasta el momento, la documentación estudiada sólo permite observar el uso de la compraventa como la forma privada de transmisión de carácter oneroso que subyace bajo la resignación ${ }^{108}$, aunque la de 1526 resultara una operación frustada. En cualquier caso, el recurso a la venta de escribanías se constata documentalmente, como en Cádiz, en Granada desde $1514^{109}$, mientras Sevilla ${ }^{110}$, Córdoba ${ }^{111}$, Málaga ${ }^{112}$ y Jerez de la Frontera ${ }^{113}$ conservan ejemplos ligeramente más tempranos. En este como en otros aspectos, el notariado público gaditano de comienzos del siglo XVI acusa características similares al andaluz y, por ende, al castellano en cuyo contexto cultural se encuadra ${ }^{114}$. Nuestros notarios se adecúan o, en su caso, se desvían de la norma

particular la de escribanías", Escribanos y Protocolos notariales en el descubrimiento de América, Madrid, 1993, pp. 97103. Asimismo, sobre la renuncia de las escribanías públicas del número para Castilla véanse BLASCO MARTÍNEZ, Rosa María, Una aproximación a la institución notarial en Cantabria, Santander, 1990, pp. 85-87; ARROYAL ESPIGARES, Pedro Juan; MARTÍN PALMA, María Teresa; CRUCES BLANCO, María Ester, Las escribanías públicas, op. cit., pp. 52-55; PARDO RODRÍGUEZ, María Luisa, "Notariado y cultura en la época colombina", PIERGIOVANNI, Vito (ed.), Tra Siviglia e Genova: notaio, documento e commercio nell'età colombiana. Atti del Convegno internazionale di studi storici per le celebrazioni colombiana, Milán, 1994, pp. 154-155; PARDO RODRÍGUEZ, María Luisa, "El notariado de Sevilla en el tránsito a la Modernidad", OSTOS SALCEDO, Pilar y PARDO RODRÍGUEZ, María Luisa (eds.), El Notariado andaluz en el tránsito de la Edad Media a la Edad Moderna. I Jornadas sobre el Notariado en Andalucía, Sevilla, 1995, p. 272; "Lo privado y lo público. Juan Álvarez de Alcalá, escribano del número de Sevilla (1500-1518)", VILLALBA PÉREZ, Enrique y TORNÉ VALLE, Emilio (eds.), El nervio de la república: el oficio de escribano en el Siglo de Oro, Madrid, 2010, pp. 17-22; OSTOS SALCEDO, Pilar, "Los escribanos públicos de Córdoba en el tránsito de la Edad Media a la Edad Moderna", OSTOS SALCEDO, Pilar y PARDO RODRÍGUEZ, María Luisa (eds.), El notariado andaluz en el tránsito de la Edad Media a la Edad Moderna. I Jornadas sobre el Notariado en Andalucía, Sevilla, 1995, pp. 189-191; OBRA SIERRA, Juan María de la, "Aproximación al estudio de los escribanos públicos del número en Granada (14971520)", OSTOS SALCEDO, Pilar y PARDO RODRÍGUEZ, María Luisa (eds.), El notariado andaluz en el tránsito de la Edad Media a la Edad Moderna. I Jornadas sobre el Notariado en Andalucía, Sevilla, 1995, pp. 140-142; ROJAS VACA, María Dolores, "Notariado público y documento", op. cit., pp. 300-301; El Documento Marítimo-Mercantil en Cádiz (1550-1600). Diplomática notarial, Cádiz, 1996, pp. 35-40; "Los escribanos públicos”, op. cit., pp. 323-326; Notariado público en Cádiz (siglos XVI-XVII), Cádiz, 2018, pp. 31-45; SAMPEDRO REDONDO, Laura, Escribanos y protocolos notariales de Gijón en el siglo XVI, Gijón, 2009, pp. 31-34; ROJAS GARCÍA, Reyes, La práctica de los escribanos públicos de Sevilla: los manuales (1504-1550), Sevilla, 2015, pp. 41-44; DOMÍNGUEZ GUERRERO, María Luisa, Las escribanías públicas del alfoz de Sevilla en el reinado de Felipe II, Sevilla, 2019.

${ }_{107}$ ROJAS VACA, María Dolores, "Los escribanos públicos”, op. cit., anexo, p. 346.

108 YBÁÑEZ BORWOYS, Pilar, "Las escribanías públicas del número en Málaga durante la etapa carolina", Baética: Estudios de arte, geografía e historia, 26, 2004, pp. 394-395, señala para Málaga el caso de una renuncia fundada en un contrato distinto de la compraventa que llama "de subrogación bajo compensación monetaria". Para los arrendamientos de escribanías, ocultos tras la renuncia, en el Cádiz del siglo XVI y los comienzos del XVII, véase ROJAS VACA, María Dolores, Notariado público, op. cit.

109 OBRA SIERRA, Juan María de la, op. cit., p. 141; ROJAS VACA, María Dolores, "Los escribanos públicos", op. cit.

110 PARDO RODRÍGUEZ, María Luisa, “Lo privado y lo público”, op. cit., pp. 22-23.

111 OSTOS SALCEDO, Pilar, "Los escribanos públicos", op. cit., p. 191.

112 ARROYAL ESPIGARES, Pedro Juan; MARTÍN PALMA, María Teresa; CRUCES BLANCO, María Ester, Las escribanías públicas, op. cit., pp. 54-55; "Sobre los orígenes de la institución notarial en Málaga", OSTOS SALCEDO, Pilar y PARDO RODRÍGUEZ, María Luisa (eds.), El Notariado andaluz en el tránsito de la Edad Media a la Edad Moderna. I Jornadas sobre el Notariado en Andalucía, Sevilla, 1995, pp. 66-67.

113 ROJAS VACA, María Dolores, "Notariado público y documento", op. cit., p. 301.

114 Sobre el notariado andaluz en la época que nos ocupa véanse para Sevilla, BONO HUERTA, José; UNGUETI, Carmen, Los protocolos sevillanos de la época del descubrimiento, Sevilla, 1986, pp. 25-37; PARDO 
en los mismos supuestos y en igual medida que sus colegas andaluces y castellanos. Por demás, el tráfico privado de cargos, oculto a partir del siglo XV tras la institución de la renuncia, se enmarca en un proceso progresivo de patrimonialización de los oficios públicos que, extendido por toda Castilla y fuera de ella, habría de culminar en tiempos de Felipe III y de Felipe IV con la concesión de las perpetuidades ${ }^{115}$.

En los dos pleitos gaditanos, los notarios alegan desconocer la ley que prohíbe este tipo de transacción para traspasar las escribanías y, en general, los oficios públicos. Incluso, ya vimos cómo González negaba su existencia ${ }^{116}$. Aparentemente, ninguno sufre las consecuencias punitivas de su transgresión. Aunque, con intereses varios, es una práctica que, denunciada por el Ayuntamiento, parece tolerada por el Consejo Real, desconocemos si a cambio del pertinente servicio, y ello tanto en lo que respecta al comprador del oficio en 1515, Diego González, cuanto al vendedor en 1526, Diego Ramírez, quienes, habilitados por sus respectivos títulos, terminarán ejerciéndolos.

Hay que subrayar la implicación de una familia de conversos en ambos litigios con idéntico propósito, cual es ocupar una escribanía numeraria de la localidad, pero con resultado desigual. Asimismo, cabe hacer notar la desconfianza de parte de la población gaditana hacia los cristianos nuevos tanto por su condición cuanto por la descompensación que supone, en el contexto de los siete notarios ejercientes, el ejercicio simultáneo del cargo por tres hermanos judeoconversos. Respecto a la norma, las Partidas, por un lado, imponían

RODRÍGUEZ, María Luisa, "Notariado y cultura", op. cit., pp. 145-186; "El notariado de Sevilla", op. cit., pp. 257-291; "Lo privado y lo público", op. cit., pp. 15-53; ROJAS GARCÍA, Reyes, La práctica de los escribanos, op. cit., pp. 17-45; para Córdoba, OSTOS SALCEDO, Pilar, "Los escribanos públicos", op. cit., pp. 171-256; EXTREMERA EXTREMERA, Miguel Ángel, El notariado, op. cit; ; para Granada, OBRA SIERRA, Juan María de la, "Aproximación", op. cit., pp. 127-170; CRESPO MUÑOZ, Francisco Javier, El notariado en Baza (Granada) a comienzos de la edad moderna. Estudio y catálogo de los protocolos notariales (1510-1519), Granada, Universidad, Facultad de Filosofía y Letras, Departamento de Historia Medieval y Ciencias y Técnicas Historiográficas, (tesis doctoral), http://hdl.handle.net/10481/1575 [consulta: 28/11/2018], 2007, pp. 115-173; para Málaga, ARROYAL ESPIGARES, Pedro Juan; MARTÍN PALMA, María Teresa; CRUCES BLANCO, María Ester, Las escribanías públicas, op. cit.; "Sobre los orígenes", op. cit., pp. 47-73; El notariado en Málaga durante la Edad Moderna. Estructura organizativa, Málaga, 2007; YBÁÑEZ BORWOYS, Pilar, op. cit.; ESCALANTE JIMÉNEZ, José, Los escribanos en Antequera. Un análisis global (1475-1869), Málaga, Universidad, Facultad de Filosofía y Letras, Departamento de Historia Moderna y Contemporánea, (tesis doctoral), https://riuma.uma.es/xmlui/handle/10630/10127 [consulta: 28/11/2018], Málaga, 2015, pp. 75-106; para Jerez de la Frontera, ROJAS VACA, María Dolores, "Notariado público y documento", op. cit., pp. 293-338; "Jerez de la Frontera: privilegio, uso y costumbre en el nombramiento de escribanos del número", BAREA RODRÍGUEZ, Manuel y ROMERO BEJARANO, Manuel (eds), 750 aniversario de la incorporación de Jerez a la Corona de Castilla: 1264-2014), Jerez de la Frontera, 2014, pp. 577-602 y, para Cádiz, ROJAS VACA, María Dolores, “Los escribanos públicos”, op. cit., pp. 301-351; "Notariado público", op. cit. Para el resto de Castilla e Indias véase la bibliografía incluida en ROJAS VACA, María Dolores, "El documento notarial de Castilla en época Moderna", MARSILLA DE PASCUAL, Francisco (ed.), Diplomática antigua. Diplomática moderna. III Jornadas de la SECCTTHH, Boletín de la Sociedad Española de Ciencias y Técnicas Historiográficas, 3, Murcia, 2006, pp. 80-95.

115 HERNÁNDEZ BENÍTEZ, Mauro, op. cit., pp. 708-709.

116 ROJAS VACA, María Dolores, “Los escribanos públicos”, op. cit., p. 324. 
que los notarios fuesen cristianos ${ }^{117} \mathrm{y}$, por otro, establecían que los conversos podían acceder a cualquier cargo público igual que los cristianos viejos ${ }^{118}$. Sin embargo, la "permisiva" legislación de Partidas se endureció durante los siglos XIV y XV, dado el sentimiento antijudío popular y al tiempo que tenían lugar las persecuciones y conversiones forzosas ${ }^{119}$. Los Reyes Católicos añadirían la prescripción según la cual ningún reconciliado ni hijo ni nieto de condenado por la inquisición pudiera usar ni tener oficios públicos, alcanzándoles la inhabilitación por vía femenina a un grado y por la masculina a $\operatorname{dos}^{120}$, reafirmándolo en otra disposición ${ }^{121}$. Sin embargo, en la práctica y pese al clima hostil, lo cierto es que los judeoconversos ejercieron como notarios en distintas poblaciones andaluzas y, en general, castellanas. Cádiz no fue una excepción.

Al margen del caso de los conversos, entre los cristianos viejos la vinculación familiar no parece unir al colectivo notarial gaditano, ni diacrónica ni sincrónicamente considerado. Una simple ojeada a los 25 títulos que, a través de la renuncia, se expiden entre 1502 y 1542 revela la sucesión familiar en el cargo, por la vía de la resignación, sólo en dos supuestos. Uno en 1524, cuando Gonzalo García renuncia en su yerno Manuel Ferraz, y otro en 1530, cuando Fernán Sánchez lo hace en su hijo Felipe ${ }^{122}$.

El Consejo Real pasa por alto, tanto en 1515 como en 1526, los requisitos personales exigidos a los escribanos del número y a los aspirantes a serlo relativos a la religión cristiana, a la mayoría de edad y a la seglaridad ${ }^{123}$ pues, pese a las denuncias, procede a expedir las concesiones oportunas. La situación de converso de Díaz era algo innegable pero no fue obstáculo para que, como antes su hermano, consiguiera la merced habilitante. Tampoco la menor edad, estado que González se negaba a admitir y que Díaz asume, supone inconveniente alguno ya que, en la carta remitida a sus hermanos, declara cómo, a criterio de Villanueva, me ayuda mucho ser menor porque no pude renunçiar el derecho que tenía en mi favor, esto es, el consejero estima que podría ser una baza favorable contra las aspiraciones de Ramírez. En cuanto a la condición de clérigo con corona abierta de Díaz denunciada por Inés de Pareja, creemos que debió ser una acusación infundada dada su nula repercusión en las respuestas de los testigos a la información enviada por esta al Consejo ${ }^{124}$ y en el interrogatorio posterior planteado por Ramírez. Tampoco prosperó en el pleito de $1515^{125}$.

117 P 3, Tít 19, L 2

118 P 7, Tít 24, L 6.

119 CARRACEDO FALAGÁN, Carmen, op. cit., pp. 62- 64.

120 NR Lib 8, T 3, L 3.

${ }^{121}$ NR Lib 8, T 3, L 4.

122 Idem.

123 BONO HUERTA, José, Historia, op. cit., pp. 212-219; Breve introducción a la Diplomática notarial española (Parte 1), Sevilla, 1990, pp. 25-26.

124 AGS, CRC, 87, 7-I, fol 15r.

125 ROJAS VACA, María Dolores, “Los escribanos públicos”, op. cit. 
De otro lado, la idoneidad moral o buena fama constituyó otro de los requisitos impuestos al aspirante a notario ${ }^{126}$ y de natural obligado a su condición durante el ejercicio del cargo. Este justificado y primordial requisito, que suponía la honradez legal y moral del notario o aspirante, implicaba estar ajeno de reprobación legal por motivo de infamia en la que incurría el condenado por falsario, y de reprobación moral por causa de vida obscena ${ }^{127}$. No obstante, ejemplos de conducta amoral e ilegal tenemos en ambos litigantes ${ }^{128}$. Al respecto, algunos testigos de Díaz denuncian a Ramírez por falsario. Al parecer, incurrió en falsedad al autorizar un censo, impuesto sobre las casas de un vecino, cuya censualista, Guiomar González, estuvo ausente cuando la escritura se otorgó ${ }^{129}$. Habiendo dado fe de que estaba presente incumplió el deber de veracidad inherente a la función notarial por alterar la verdad de las circunstancias del otorgamiento ${ }^{130}$. Asimismo, citan otros tres supuestos de ilegalidad que atañen a la actividad documental desarrollada por este escribano. Según Antonio de Urdiales, Diego Ramírez dio fe de la notificación de una ejecutoria, librada por la Cancillería de Granada a favor de un vecino y contra sus sobrinos, sin habérsele notificado como tutor e incluso poniendo por testigos a dos criados suyos ${ }^{131}$. En un compromiso arbitral, autorizado por Ramírez, que zanjó el litigio sostenido entre Pedro de Medina y su nieto, sentenciaron dos árbitros, el licenciado Pérez y el bachiller Frías, dando de lado al licenciado Verdugo, alcalde de la ciudad, nombrado con aquéllos para determinarlo ${ }^{132}$. En fin, el mismo Medina refiere también las quejas del vecino Vizconte Lucián contra Ramírez por cuanto le hizo una probanza sin poner en algunos dichos de los testigos lo que los testigos declaravan ${ }^{133}$.

126 P 3, Tít 19, L 2.

127 BONO HUERTA, José, Historia, op. cit., p. 219.

128 Sobre conducta delictiva tocante a los notarios véase MORENO TRUJILLO, María Amparo, "La conflictividad de los escribanos en el ejercicio de sus funciones: Mala praxis y... algo más”, MORENO TRUJILLO, María Amparo, OBRA SIERRA, Juan María de la y OSORIO PÉREZ, María José (Coords.), El notariado andaluz: institución, práctica notarialy archivos: siglo XVI, Granada, 2011, pp. 269-296, y para todo tipo de escribanos véanse VILLALBA PÉREZ, Enrique, "Sospechosos en la verdad de lo que pasa ante ellos: los escribanos de la Corte en el Siglo de Oro, sus impericias, errores y vicios", Litterae: cuadernos sobre cultura escrita, 2, 2002, pp. 121-149 y VILLALBA PÉREZ, Enrique; NEGREDO, Fernando, "Escribanos en defensa de su oficio", VILLALBA PÉREZ, Enrique y TORNÉ VALLE, Emilio (eds.), El nervio de la república: el oficio de escribano en el Siglo de Oro, Madrid, 2010, pp. 153-182; EXTREMERA EXTREMERA, "El delito en el archivo. De escribanos, falseadores y otras gentes de mal vivir en la Castilla del Antiguo Régimen", Hispania: Revista española de historia, LXV/2, núm. 220, 2005, pp. 465-484 y, extendida a todos los colectivos sociales en la España del Antiguo Régimen, véanse PONCE LEIVA, Pilar, "Percepciones sobre la corrupción en la Monarquía Hispánica, siglos XVI y XVII”, ANDÚJAR CASTILLO, Francisco y PONCE LEIVA, Pilar (eds.), Mérito, venalidad y corrupción en España y América. Siglos XVII y XVIII, Valencia, 2016, pp. 193-211; GÓMEZ GONZÁLEZ, Inés, "Corrupción moral versus corrupción profesional: percepción, persecución y castigo en el Antiguo Régimen”, ANDÚJAR CASTILLO, Francisco, PONCE LEIVA, Pilar (coords). Debates sobre la corrupción en el mundo ibérico, siglos XVI-XVIII, Alicante, 2018, pp. 103-114.

129 Alonso Galíndez de Amar, vecino de Cádiz, preg. 21; Ramírez en la preg. 9, Pedro Lorenzo, vecino de Cádiz, compadre de Diego Ramírez, preg. 7; Jaime de Luna, veinticuatro de Jerez y regidor de Cádiz, preg. 9; Pedro de Cardona, alguacil, preg. 9; Jaime de Ralfás, mercader aragonés, estante en Cádiz, preg. 9.

130 BONO HUERTA, José, Historia, op. cit., pp. 314-315.

131 Antonio de Urdiales, vecino de Cádiz, preg. 21.

132 Pedro de Medina, vecino de Cádiz, preg. 21.

133 Idem. 
Igualmente, no es muy moral, aparte de ser ilegal, la enajenación de la dote de su mujer que lleva a cabo Ramírez ${ }^{134}$ que, como sabemos, estaba prohibida por ley y cuyas consecuencias económicas y éticas para el desarrollo del matrimonio y el estado de su esposa e hijos relatan los testigos con elocuentes palabras.

En la misma línea delictiva, Díaz reaccionaba ante una pendencia con un vecino mediante una agresión física. Parece que acuchilló la mano de Gaspar de Haya por palabras que tuvieron tras incluirlo Díaz en un libelo infamatorio ${ }^{135}$, lo que generó la pertinente pesquisa, mandamiento de prisión y encarcelación. Resuelto inicialmente al presentarse ante el lugarteniente del corregidor en vn aposyento que está sobre la cárçel desta çibdad, donde se despachó el tema, volvería a motivar los mandamientos de prisión dados en su contra al tiempo de regresar de la Corte. Y si de delitos y familia se trata, no menos inmoral es la conducta de su hermano, el notario Diego González, quien, casado en legítimo matrimonio, se echó carnalmente con la hermana de su esposa y cuñada, con la cual tuvo una hija, tras enviudar aquella del doctor Acevedo, el marido. Delito de adulterio que, en opinión del denunciante, por ser de sobra conocido y no denunciado, merecía la excomunión de todos y cada uno de los vecinos ${ }^{136}$.

Los requisitos de aptitud, habilidad y suficiencia, aplicables también a los notarios en ejercicio, suponían, de un lado, el dominio de la redacción de los documentos y, de otro, poseer el saber jurídico preciso para su correcta formulación negocial ${ }^{137}$. Hemos de presumir que ambos litigantes cumplían estos requisitos, Díaz porque había superado el examen ante el Consejo y Ramírez, además, por haber desarrollado una práctica continuada a lo largo de catorce años de servicio. Una antigüedad y experiencia que sus testigos celebran, según vimos, y que le convierten en centro de sus preferencias. Sin embargo, los de Díaz encuentran deficiencias en el quehacer profesional de este notario. Para estos, Ramírez incumple el deber de asistencia $^{138}$ desde el momento en que es capaz de abandonar el oficio, la audiencia y de no atender a la clientela a causa de su adicción al juego de cartas. Son significativas las declaraciones de los mismos, en las que, tras ratificar su adicción, relatan de oídas, de visu o en calidad de afectados, en primera persona, cómo Ramírez no sólo faltaba al oficio y a la audiencia dejando de lado a su posible clientela sino que, por estar jugando, la evitaba y se

\footnotetext{
134 Apéndice doc $\mathrm{n}^{\circ} 1$.

135 Ramírez en la preg. 9, Pedro Lorenzo, vecino de Cádiz, compadre de Diego Ramírez, preg. 7; Jaime de Luna, veinticuatro de Jerez y regidor; vecino de Cádiz, preg. 9; Pedro de Cardona, alguacil de Cádiz, preg. 9; Jaime de Ralfás, mercader aragonés, estante en Cádiz, preg. 9.

136 Nuño de Cepeda, preg. 10.

137 P 3, Tít 19, L 2.

${ }^{138}$ Entendido como la "obligación de prestar el ministerio propio del oficio (i. e. la escrituración pública de los negocios jurídicos) a quien lo solicitara”, BONO HUERTA, José, Historia, op. cit., pp. 317-320.
} 
negaba a formalizar las escrituras que solicitaban. Ilustrativo es el testimonio del mercader de Egio, estante en Cádiz, Jácome Justinián quien, theniendo negoçios ante él, biéndole a buscar a su casa se mandó negary después este testigo le vio por entre la puerta que estaba jugando con Françisco de León e con vn Barrán e con otros vezinos desta dich a çibdad ${ }^{139}$ o, más suave y "quitándole hierro al asunto", el caso de su compañero, el también notario, Diego Sánchez que confesaba haberle visto jugar a los naipes muchas vezes y en quanto al residir de su ofiçio que es onbre que, estando desocupado, los despacha muy bien tanto como otro e más e que, algunas vezes, le a visto buscar a algunos negoçiantes, como fazen a otros escriuanos, e no ballarle ${ }^{140}$. Ramírez, pues, es tan hábil y suficiente o más que sus colegas pero le pierde el vicio del juego.

Por otro lado, el cobro abusivo de derechos contravenía el deber de asistencia ya que constituía una extralimitación de su función ${ }^{141}$. En este sentido, la mayoría de los testigos de Díaz acusan a Ramírez, con carácter general, de percibir honorarios excesivos ${ }^{142}$. Usualmente, además, recogen situaciones específicas. Con frecuencia repiten el caso del pescador, avecindado en Cádiz, Juan Bautista a quien Ramírez, por buscar y sacar una escritura de los registros de Juan de Haya, su antecesor, cobró diez ducados correspondiéndole sólo uno ${ }^{143}$. No exento de razón, como señala el escribano de cabildo Hernán Gascón, subrayando la generalización de esta falta dentro del colectivo, Diego Ramírez e otros escribanos desta çibdady avn de fuera della a las vezes cobran más derechos de los que les pertenesçen ${ }^{144}$.

Sin embargo, sería parcial y tendencioso terminar omitiendo el lado amable, generoso y profesional de Ramírez, cualidades a las que, por razones obvias, aluden sus propios testigos. En efecto, frente a los testigos de Díaz y enlazando con el tema de los honorarios, el barbero Francisco Fernández Duque observa que le a vysto vsar el ofiçio byen e fielmente e ser byen quisto e a visto que a buelto sus derechos a personas nesçesytadas ${ }^{145}$. Por su parte, Nuño de Cepeda precisa que tyene otra eçelençia entre todos los escriuanos del reyno que avnque tal como oy pasen ante él veynte o çinqüienta escripturas quando amanesçe ninguna está por registrar ${ }^{146}$, alabando, entre otras facultades, la diligencia y efectividad, excepcional frente al resto de los escribanos del reino, con que

\footnotetext{
139 Jácome Justinián, mercader de Egio, estante en Cádiz, preg. 29.

140 Diego Sánchez, escribano del número y vecino de Cádiz, preg. 29.

141 BONO HUERTA, José, Historia, op. cit., p. 319.

142 Pregunta 29 del interrogatorio de Ramírez. Hernán Gascón, escribano del cabildo y vecino de Cádiz, preg. 29; Diego Sánchez Bernalte, regidor y vecino de Cádiz, preg. 29.

143 Diego Sánchez, escribano del número y vecino de Cádiz, preg. 29; Francisco García, hijo de don García de la Cerda, vecino de El Puerto de Santa María, estante en Cádiz, preg. 21; Cristóbal Díaz, hijo de Jorge Díaz, vecino de Cádiz, primo de Cristóbal Díaz, preg. 21.

144 Hernán Gascón, escriuano del cabildo y vecino de Cádiz, preg. 29.

145 Francisco Fernández Duque, barbero, preg. 10.

146 Nuño de Cepeda, preg. 8.
} 
acomete la registración o protocolización de las escrituras ${ }^{147}$. Este deber de registración exigía a los notarios realizar la escrituración solicitada previo asiento en el registro o protocolo y comprendía tanto la obligación de cumplir las prescripciones relativas al modo de ejecutar las distintas fases de escrituración como la de hacerlas en los plazos señalados ${ }^{148}$.

Los pleitos gaditanos de 1515 y 1526 evidencian bastantes similitudes y escasas particularidades. Entre estas últimas, la más destacable reside en la imposibilidad de Díaz de presentar la provisión regia en el Ayuntamiento, solemnidad acostumbrada y necesaria para su entrada en ejercicio, como consta en los propios títulos ${ }^{149}$. El lugarteniente de corregidor Téllez y el regidor Luna, contra la prescripción real y acudiendo a amenazas y extorsiones, lo impiden quizás conscientes de que su opción no obtendría el respaldo suficiente de los cabildantes. Son once los regidores que suscriben la carta de apoyo a Díaz ${ }^{150}$ de un máximo de dieciocho ${ }^{151}$. Numéricamente, por tanto, estaban en minoría. Por su parte, González no

147 Acerca del sistema documental impuesto a los notarios castellanos por Isabel I en la Pragmática de Alcalá de 1503, véase Libro de las Bulas y Pragmáticas de los Reyes Católicos, T. II, 1973, pp. 361v.-364r. Estudian la norma y su aplicación práctica RODRÍGUEZ ADRADOS, Antonio, "La Pragmática de Alcalá, entre las Partidas y la Ley del Notariado", Homenaje a Juan Berchmans Vallet de Goytisolo, 7, Madrid, 1988, pp. 517-813, sobre los documentos de la práctica, OSTOS SALCEDO, Pilar, "Diplomática notarial en la época colombina: Fases de redacción y forma documental", PIERGIOVANNI, Vito (ed.), Tra Siviglia e Genova: notaio, documento e commercio nell'età colombiana. Atti del Convegno internazionale di studi storici per le celebrazioni colombiana, Milán, 1994, pp. 198-204; "Los escribanos públicos", op. cit., pp. 201-256; MORENO TRUJILLO, María Amparo, "Diplomática Notarial en Granada (1505-1520)", OSTOS SALCEDO, Pilar y PARDO RODRÍGUEZ, María Luisa (eds), El Notariado andaluz en el tránsito de la Edad Media a la Edad Moderna. I Jornadas sobre el Notariado en Andalucía, Sevilla, 1995, pp. 75-125; OBRA SIERRA, Juan María de la; MORENO TRUJILLO, María Amparo, "La práctica notarial posterior a la Pragmática de Alcalá: unos cuadernos de notas de Baza (1535)", MARÍN LÓPEZ, Rafael (ed.), Homenaje al profesor Dr. D. José Ignacio Fernández de Viana y Vieites, Granada, 2012, pp. 352-368; ROJAS VACA, María Dolores, "Notariado público y documento", op. cit; ROJAS GARCÍA, Reyes, op. cit;; DOMÍNGUEZ GUERRERO, María Luisa, op. cit.

148 BONO HUERTA, José, Historia, op. cit., pp. 319-320.

149 ROJAS VACA, María Dolores, "Los escribanos públicos”, op. cit., pp. 334-336, así por ejemplo en el título de Diego González se prescribe: "E, por esta mi carta, mando al conçejo, justiçia, regidores, caualleros, escuderos, oficiales e ommes buenos de la dicha çibdad de Cádiz que, luego que con ella fueren requeridos syn esperar para ello otra mi carta ni mandamiento ni segunda ni terçera jusyón, juntos en su cabildo e Ayuntamiento, según que lo han de vso e de costunbre, tomen e reçiban de vos, el dicho Diego Gonçález, el juramento e solenidad que en tal caso se requiere e devéys fazer. El qual asý fecho vos ayan e reçiban e tengan por mi escriuano del número de la dicha çibdad de Cádiz, en lugar del dicho Christóval Arias, e vsen con vos en el dicho ofiçio y en todos las cosas e casos a él anexas e conçernientes e vos guarden e fagan guardar todas las honrras, graçias, merçedes, franquezas e libertades, esençiones, preminençias, prerogativas e ynmunidades que por razón del dicho ofiçio devéys aver e gozar e vos deven ser guardadas e vos recudan e fagan recudir con todos los derechos e salarios e otras cosas al dicho ofiçio anexas e perteneçientes, sý e segund que se ha vsado, guardado e recodido, asý al dicho Christóval Arias como a cada vno de los otros mis escriuanos que han seydo e son de la dicha çibdad. //3r. De todo bien e conplidamente en guisa que vos non mengüe ende cosa alguna que yo, por la presente, vos reçibo e he por reçebido al dicho ofiçio e al vso y exerçiçio dél. E vos doy poder e facultad para lo vsar y exerçer caso que por los susodichos o por alguno de ellos a él no seáys reçebido. La qual dicha merçed vos fago con que os ayáis de presentar e presentéys con esta mi carta en la casa del cabildo e Ayuntamiento de la dicha çibdad dentro de sesenta días primeros syguientes que se cuente desde el día de la fecha de ella en adelante. Y que sy asý no lo fizierdes ayáis perdido e perdáys el dicho ofiçio e quede vaco para yo poder hazer merçed dél a quien mi voluntad fuere".

150 Apéndice doc $n^{\circ} 9$.

151 Contabilizamos 18 regidores en Cádiz antes de los acrecentamientos de 1543, ROJAS VACA, María Dolores, Notariado público, op. cit., pp. 81-82. 
encuentra este escollo. Presenta la carta de merced en el cabildo municipal sin aparentes problemas aun cuando la mayoría de las autoridades locales suplican de sus efectos y suspenden la recepción a la espera de la decisión regia ${ }^{152}$, acogiéndose al postulado según el cual las provisiones podrán ser obedecidas y no cumplidas si son contrarias a Derecho ${ }^{153}$. Como consecuencia, el pleito aquí lo inicia la ciudad, en tanto que el de 1526 parte del escribano de los reinos Cristóbal Díaz quien, de otro lado, se enfrenta a un escribano del número "bien relacionado" y todavía en ejercicio, mientras González en 1515 venía a ocupar el oficio de un notario huido. También el resultado del proceso es distinto. González gana la causa. Díaz se aparta de ella, desiste en beneficio de su adversario.

En fin, el litigio que nos ha ocupado descuella por la riqueza de información que transmite acerca de la sociedad gaditana y, por extensión, de la castellana coetánea de la cual el colectivo notarial es un grupo destacado, pues su dominio de la escritura, en una comunidad fundamentalmente ágrafa, y su conocimiento de la praxis jurídica le convierte en una élite de poder letrada ${ }^{154}$.

\section{Apéndice documental}

1512, enero, 17. Cádiz

Diego Ramírez de la Rúa, vecino de Cádiz, declara recibir en dote de Inés de Pareja, su esposa, bija de Álvaro de Pareja, vecino de Cádiø, 70.000 maravedíes.

B.- AGS, CRC, 87, 7-I, fols 15r.-16r. Copia inserta de traslado autorizado por Diego González en 26 de septiembre de 1517.

A todos quantos la presente vieren, que Dios honrre y guarde de mal.

Yo, Diego Gonçález, escriuano público del número de la muy noble çibdad de Cádiz por los reyes, nuestros señores, e su escriuano e notario público en la su corte e en todos los sus reynos e señoríos, me vos mucho encomiendo e hago saber e doy fee que en los libros e registros que quedaron e fincaron de Christóval Arias, escriuano público que fue desta dicha çibdad, mi anteçesor, en cuyo ofiçio yo suçedí, está escrita e asentaba vna carta de dote que pareçe que hizo e otorgó, ante el dicho Christóval Arias, Diego Ramírez de la Rúa, vezino desta dicha çibdad, a Ynés de Pareja, su esposa, según por ella pareçía, el tenor de la qual es este que se sygue:

In Dei nomine, amén. Sepan quantos esta carta vieren cómo yo, Diego Ramírez de la Rúa, vezino de la noble çibdad de Cádiz, otorgo e conozco que reçibo e he

\footnotetext{
152 ROJAS VACA, María Dolores, “Los escribanos públicos”, op. cit., pp. 304-305.

153 BONO HUERTA, José, Historia, op. cit., p. 288; GONZÁLEZ ALONSO, Benjamín, "La fórmula "Obedézcase pero no se cumpla" en el Derecho castellano de la Baja Edad Media", Anuario de historia del derecho español, 50, 1980, p. 483.

${ }^{154}$ COSTAMAGNA, Giorgio, op. cit:; TAMBA, Giorgio, op. cit.
} 
reçebydo de vos e con vos, Ynés de Pareja, mi esposa, hija de Álbaro de Pareja, vezino de la dicha çibdad, en dote e casamiento setenta mill maravedíes de la moneda vsual corriente en Castilla, los quales reçebý en esta manera: los çinqüenta mill maravedíes dellos en dineros contados, e los veynte mill maravedíes //15v. en axuar e preseas de casa que los valió e montó, de que me doy e otorgo e tengo de vos por bien contento e pagado e entregado a toda mi voluntad por quanto pasaron a mi poder realmente e con efeto, sobre lo qual renunçio la eçepçión de la non numerata pecunia e las dos leyes del derecho de la prueva e de la paga, según que en ellas e en cada vna dellas se contiene.

Por ende, por esta presente carta, me obligo e prometo de tener en pie e manifiesto los dichos setenta mill maravedíes como bienes dotales e palafrenales e de vos los dar e acudir con ellos todo el tienpo e sazón que el matrimonio fuere disuelto por qualquier de los casos que el derecho dispone dentro de ocho días primeros syguientes, so pena del doblo e la pena, pagada o no pagada o graçiosamente remitida, que todavía vos dé e pague los dichos setenta mill maravedíes del dicho vuestro dote e cabdal. E para mayor seguridad vos obligo e ypoteco e doy en peños e por nonbre de peños todos mis bienes, muebles e raýzes e semovientes, quantos el día de oy yo he e tengo e toviere de aquí adelante e, en espeçial, vn esclavo que ha por nonbre Luis para que los tengades en vuestro poder e posesión e no seades dellos desapoderada hasta que, primeramente, seades contenta e pagada de los dichos setenta mill maravedíes, en los quales vos misma, por vuestra propia abttoridad e sin liçençia ni mandado de juez, vos podáys entregar en lo mejor parado de mis bienes o en lo que vos quisierdes e cada e quando que quisierdes.

E, por esta dicha carta, ruego e pido e doy e otorgo todo mi poder cunplido a todas e qualesquier justiçias e juezes ante quien esta carta pareçiere e fuere pedido conplimiento de justiçia para que, por todo rygor de derecho, me costringan e apremien e hagan cunplir e pagar //16r. lo contenido en esta dicha carta e cada vna cosa e parte dello. E para ello obligo la dicha mi persona e todos los dichos mis bienes e renunçio de mi favor todas e qualesquier leyes de que me pudiese ayudar y aprovechar, asý de fuero como de derecho e de vso e de costunbre, e todas buenas razones, exsebçiones e defensyones e firmes renunçiaçiones que sean en mi favor e la ley del derecho en que dize que general renunçiaçión fecha no vala salbo sy esta ley fuera renunçiada.

Fecha la carta en la dicha çibdad de Cádiz, diez e syete días del mes de enero, año del nasçimiento de nuestro Salbador Iesuchristo de mill e quinientos e doze años.

Testigos que fueron presentes, llamados e rogados: Polo de la Caxina e Juan Batista Biaxa e Jaime de Luna, estantes en la dicha çibdad.

E firmélo de mi nombre en el registro del escriuano. Diego Ramírez.

La qual dicha escritura de dote yo, el dicho escriuano, hize sacar de los dichos registros e la hize corregyr e conçertar con el dicho oreginal onde fue sacada, en la muy noble çibdad de Cádiz, sábado veynte e seys días del mes de setienbre, año del nasçimiento de nuestro Salbador Iesuchristo de mill e quinientos e diez e syete años.

Testigos que fueron presentes e la vyeron sacar, corregir e conçertar: Alonso de Medina e Tomás de la Casyna, vezino e estante en esta çibdad.

Yo, Diego Gonçález, escriuano público del número de la muy noble çibdad de Cádiz por la reyna e el rey, su hijo, nuestros señores, e su escriuano e notario público en la su corte e en todos los sus reynos e señoríos, lo fiz escriuir e fiz aquí mío signo a tal, en testimonio de verdad. Diego Gonçález, escriuano público. 
1526, marzo, 10. Cádiziz ${ }^{15}$.

Diego Ramírez de la Rúa, escribano público del número de Cádiz, ante el lugarteniente de corregidor de Cádiz, reclama y contradice la renuncia del oficio a favor de Cristóbal Díaz. (13 de febrero), dándola el alcalde por ninguna.

AGS, CRC, 87, 7-I, fol 10r.-v.

En la muy noble e leal çibdad de Cádiz, sábado, diez días del mes de março, año del nasçimiento de nuestro Salbador Iesuchristo de mill e quinientos e veynte e seys años.

Ante el muy noble señor, el liçençiado Diego Téllez, teniente de corregidor e alcalde mayor en logar del noble cavallero, el señor Fernán Pérez de Torres, corregidor e justiçia mayor de la dicha çibdad por el enperador e por la reyna, nuestros señores, en presençia de mí, Lope de Medina, escriuano público, pareçió ý presente Diego Ramírez de la Rúa, escriuano público de la dicha çibdad, e dixo que por quanto a los treze días del mes de hebrero próximo pasado deste dicho año él ovo renunçiado e renunçió su ofyçio de escrivanía pública para que su Magestad hiziese merçed a Christóval Díaz, estante en esta dicha çibdad, por dineros que le dieron y porque es ynformado que no lo pudo hazer conforme a las leyes destos reynos y capýtulos de Cortes y, demás desto, la dicha renunçiaçión fue en grave daño e perjuyzio de Ynés de Pareja, su muger, e de su dote. Por ende que reclamava e reclamó e contradezía e contradixo la dicha renunçiaçión e la dava e dio todo por ninguno e de ningún vigor e efeto e que los dyneros que reçibyó está presto de los bolver, reteniendo como retyene todavía en sý el ofiçio de escrivanía.

E que lo pedýa e pydió por testimonio, de lo qual fueron testigos: Diego Ortiz, alguazil, e Pero Gil, vezinos de la dicha çibdad.

E luego el dicho señor alcalde mayor, vista la dicha reclamaçión del dicho Diego Ramírez y porque en su presençia a pareçido la dicha //10v. Ynés de Pareja a hazer la misma reclamaçión, dixo que pronunçiava e declarava e pronunçió e declaró la dicha renunçiaçión fecha por el dicho Diego Ramírez por ninguna e que le mandava e mandó que deposyte los dineros que ha reçibydo para que dellos se haga lo que sus Magestades mandaren. E mandólo dar asý por testimonio. Testigos los dichos.

El liçençiado Téllez (rúbrica).

E yo se lo dy todo al dicho Diego Ramírez, signado con mi signo e firmado de mi nonbre. Testigos los dichos.

E yo, Lope de Medina, escriuano público del número de la muy noble e leal çibdad de Cádiz por sus Magestades, la fyz escreuir e escreuí según que ante mí paso e, por ende, fyz aquí este mío sig(signo $)$ no a tal en testimonio de verdad.

Lope de Medina, escriuano público (rúbrica).

1526, marzo, 24. Cádiz

Cristóbal Díaz, escribano de los reinos, reclama y contradice cualquier renuncia otorgada a favor de Diego Ramirez de la Rúa, escribano del número de Cádiæ, sobre la escribanía que le vendió.

B.- AGS, CRC, 87, 7-III, sf, copia inserta en el interrogatorio de testigos de Díaz, presentada para mostrarla tras la preg. 18 .

155 Presentada en el Consejo Real el 27 de abril. 
En la noble e muy leal çibdad de Cádiz, a veynte e quatro días del mes de março, año del nasçimiento de nuestro Salvador Iesuchristo de mill e quinientos e veynte e seys años.

Este dicho día en presençia de mí, Diego Sánchez, escriuano público del número desta dicha çibdad e de sus Magestades, e testigos de yuso escriptos paresçió presente Christóval Díaz, escriuano de sus Magestades, vezino desta çibdad, e dixo que ansý es que podrá aver quarenta días, poco más o menos, que Diego Ramírez de la Rúa, escriuano público que fue desta çibdad, le renunçió e traspasó en el dicho Christóval Díaz el dicho ofiçio de escriuanía pública que tenía e pidió e suplicó a sus Magestades le hiziesen merçed al dicho Christóval Díaz del dicho ofiçio e que él con la dicha renunçiaçión fue ante sus Magestades e los señores del su Consejo e le hizieron merçed del dicho ofiçio e le mandaron dar e dieron su carta e provisión real de él para que fuese reçebido al dicho ofiçio. E que agora él a benido a esta çibdad para presentar la dicha provisión al cabildo e regimiento desta çibdad para ser reçebido al dicho ofiçio donde a visto e sabido que el dicho Diego Ramírez de la Rúa con cabtela e fraude a buscado e procurado todas las vías e formas que a podido para que el dicho Christóval Díaz no fuese reçebido al dicho ofiçio e se a llegado e confederado con Jayme de Luna, regidor desta çibdad, que tiene mucho odio y henemistad al dicho Christóval Díaz, el qual dicho Jayme $/ /$ r. de Luna es muy amigo e parçial a la justiçia e alcalde mayor desta çibdad, el qual por conplazer a los dichos Jayme de Luna e Diego Ramírez a prometido e jurado que no [avía] de resçebir al dicho ofiçio ni cunplir la dicha provisión de sus Magestades. E para que aquélla no oviese hefeto ni cunplimiento el dicho alcalde mayor e Jayme de Luna hizieron e tovieron formas que ayer biernes, que era día hordinario de cabildo, no se hiziese porque él no presentase la dicha provisión. E, demás dello, el dicho alcalde mayor e Jayme de Luna han hordenado de dar e dieron mandamiento sin cabsa ni razón para prender al dicho Christóval Díaz e tenerlo preso porque no presentase la dicha provisión e le han amenazado de le hazer mucho mal e daño si no tornase el dicho Christóval Díaz a renunçiar e traspasar el dicho ofiçio de escriuanía pública en el dicho Diego Ramírez y el dicho alcalde mayor a prometido que de tres provisiones que el dicho Christóval Díaz traya a de suplicar y el dicho Jayme de Luna a dicho de poner su estado e hazienda para que el dicho Christóval Díaz no sea resçibido a el dicho ofiçio de escriuanía por manera que han ydo e van contra lo que su Magestad a mandado e manda por la dicha su provisión real. Por ende, el dicho Christóval Díaz dixo que sy por caso él tornase a renunçiar e traspasar el dicho ofiçio de escriuanía en el dicho Diego Ramírez de la Rúa que sería por temor de no ser preso e hecho mucho mal e daño syn cabsa ni razón e de no poder presentar la dicha provisión real para ser reçibido al dicho ofiçio e que lo hazía //v. forçadamente e a más no poder y $[\ldots]$ no de su voluntad. Y que dende agora para estonçes y de estonçes para agora reclamava e reclamó e contradezía e contradixo qualquier traspaso e renunçiaçión que él hiziese del dicho ofiçio a el dicho Diego Ramírez de la Rúa e qualquier suplicaçión que sobre ello hiziere a sus Magestades para que por ella no sea hecha merçed del dicho ofiçio al dicho Diego Ramírez e que, ansý mismo, protestava e protestó de mostrar e presentar esta dicha declaraçión e reclamaçión ante sus Magestades para que sepan la verdad del caso e no hagan merçed del dicho ofiçio al dicho Diego Ramírez antes lo dexen al dicho Christóval Díaz e le den otras sus provisiones para él ser reçebido al dicho ofiçio e de conseguir e demandar su justiçia ante sus Magestades e los dichos señores del su Consejo real e que la dicha declaraçión e reclamaçión la hazía e hizo por la vía e forma que mejor e más a su derecho convenga e lo pedía e pidió por testimonio e, que ansý mismo, reclamava e reclamó e contradezía e contradixo qualquier obligaçión que hiziere sobre la dicha renunçiaçión e sobre el dicho ofiçio e cosa a él tocante para que no valiesen por las cabsas susodichas. 
1526, abril, 3. Puerto Real ${ }^{156}$.

Cristóbal Díaz, escribano de los reinos, vecino de Cádiz, presenta requerimiento ante Cristóbal López, alcalde ordinario de Puerto Real, instándole a tomar declaración a ciertos testigos.

AGS, CRC, 87, 7-II, fol 1r.-v.

En la villa de Puerto Real, villa de la muy noble e muy leal çibdad de Xerez de la Frontera, tres días del mes de abryl, año del nasçimiento de nuestro Salvador Iesuchristo de mill e quinientos e veynte e seys años. Ante el honrado señor Christóval López, alcalde hordinario de la dicha villa, y en presençia de mí, Alonso Garçía Moxarro, escriuano público y del conçejo della, paresçió Christóval Díaz, escriuano de sus Magestades, vezyno de la çibdad de Cádiz, y presentó vn escripto de requerimiento con çiertas preguntas, que su tenor es lo syguiente:

\section{Noble señor}

Christóval Díaz, escriuano de sus Majestades, vezino de la çibdad de Cádiz, parezco ante vuestra merçed e digo que asý es que podrá aver mes e medio, poco más o menos, que Diego Ramírez de la Rúa, escriuano público que a la sazón hera de la çibdad de Cádiz, me renusçió e traspasó su ofiçio de escrivanía pública que tenía e pidió e suplicó a sus Magestades me fizyesen merçed del dicho ofiçio, con la qual dicha renusçiaçión yo fue ${ }^{157}$ ante sus Magestades e me hizieron merçed del dicho ofiçio e mandaron [dar] e dieron su carta e provisión real para ser resçibido al dicho ofiçio en la dicha çibdad con la qual yo vyne a la dicha çibdad de Cádiz para ser reçibido el dicho ofiçio, donde supe cómo el dicho Diego Ramírez con mucho fravde e cavtela que tuvo procurava e procuró todas las vías e formas que pudo para que yo no fuese reçebido al dicho ofiçio e se confederó e allegó con el liçençiado Diego Téllez, alcalde mayor de la dicha çibdad, e con Jayme de Luna, regidor della, que son muy amigos e parçiales, los quales por conplazer al dicho Diego Ramírez prometieron e juraron de no reçibir a mí, el dicho Christóval Díaz, al dicho ofiçio e suplicar de tres provisyones que sobre ello presentase e el dicho Jayme de Luna dixo e prometió que avía de poner su estado e hazyenda para que yo no fuese reçebido al dicho ofiçio por enemistad que me tiene. E, demás dello, el dicho alcalde mayor sin cabsa ni razón mandó dar e dio sus mandamientos para los alguazyles que prendiesen el cuerpo a mí, el dicho Christóval Díaz, e me pusiesen en la cárçel para que no presentase ni pudiese presentar la dicha provisyón. E los dichos alguazyles me querían prender sy no me retruxera a la yglesia y, asý mismo, el dicho alcalde mayor no consyntió que el viernes de la semana de Ramos pasada que en la dicha çibdad hera día hordinario de cabildo e yo avía de presentar la dicha provisión no consyntió que se hiziese cabyldo e por muchas vías e formas el dicho alcalde mayor e Jayme de Luna me amenazaron e atemorizaron $/ / 1$ v. diziendo que me harían mucho mal e daño si no me dexase del dicho ofiçio e lo tornarse a renusçiar e traspasar en el dicho Diego Ramírez. E por mí visto todo lo susodicho con temor de los dichos alcalde mayor e Jayme de Luna que no me prendiesen e fizyesen mal e daño e con temor que no me resçebirían al dicho ofiçio e porque me librasen de lo que así me oponían, forçadamente e a más no poder y no de mi voluntad antes revocándolo e contradizyéndolo en mi ánimo e pensamiento para me querellar ante sus Magestades torné a renusçiar e trespasar el dicho ofiçio de escrivanía en el dicho Diego Ramírez sin ser a él yo resçebido y, después de renusçiado, me libraron de lo que asý me oponía el dicho alcalde mayor. E porque yo me entiendo de yr e voy a quexar e querellar ante

156 Presentada en el Consejo Real en Granada a 29 de junio de 1526.

157 Sic. 
sus Majestades e ante los dichos señores del su Consejo de lo susodicho para que no manden fazer ni fagan merçed del dicho ofiçio al dicho Diego Ramírez antes, sabida la verdad del caso, me lo dexen a mí e me den otras sus provisyones para ser reçebido al dicho ofiçio e para que sus Magestades e los dichos señores sepan la verdad del caso me cunple e conviene presentar ante vuestra merçed algunos testigos que al presente están en esta vylla e se quieren yr della e si se fuesen sin reçebir sus dichos yo reçybiría daño. Pido a vuestra merçed que, ad perpetuan rey memoria, o como mejor de derecho aya lugar, mande tomar e resçebir los dichos testigos e tomados me los mande dar en manera que faga fee para guarda de mi derecho. Sobre que pido justiçia e ynploro su ofiçio e los testigos se pregunten por las preguntas syguientes...

1526, abril, 7. Sevilla158.

Cristóbal Díaz informa a sus hermanos de sus intenciones con el pleito y progreso de las negociaciones en la Corte y demanda aprobación y dinero.

AGS, CRC, 87, 7-I, fol 34r.

$$
\text { (Crus) }
$$

Señores hermanos:

Con un inglés del Puerto les escriuí ayer e porque no se si la data sería çierta quise replicar e dezir lo que les escriuí. Yo vine a esta çibdad con otro propósyto del que dixe quando de aý me partí que fue a hazer algund daño si pudiese a Diego Ramírez pues tanto procuró de hazernos e pedíos por merçed por mi carta que lo oviéseys por bien e nos enojáseys porque yo tengo dada petiçión en casa del secretario Covos sobre ello e hablado e ynformado a los señores dotor Caravajal e don García haziéndoles saber cómo avía pasado e me dixeron que diese la dicha petiçión para que no se pasase el título e que en el Consejo me harían justiçia.

El lunes tengo de dar petiçión en el Consejo Real, dízeme el señor Villanueva que tengo justiçia e que él fará la petiçión e que me ayuda mucho ser menor porque no pude renunçiar el derecho que tenía en mi favor. E oy vide aquí a Pareja que paresçe que vino con el despacho. Supo en casa de Covos donde se yva a despachar cómo estava dada la petiçión. Vino a mí llorando que no se diese mal tras mal e yo le respondí que todo se haría bien e que razón tenía yo de hazer todo e más pues tan mal se hizo conmigo.

En verdad aquí todos se an espantado de hazer lo que se hizo. Benavides e Pero Antonio dixeron tal es posyble, pesóles en el ányma e dixéronme otras muchas cosas que algund día os diré.

Vuestra Reverençia me dixo dize luego os dirán ${ }^{159}$ sobrecarta syn enbargo de todo eso que hera ayar vn alguazil pidiéndolo firá luego a poneros en posesyón. Asý que mira sy terné razón de yntentar e fazer lo que pudiere. No me escriváys que me dexe dello porque no lo tengo de hazer e sy no me aprovechare estaré paçiençias. Provéeme de dineros sy mandardes y enbía los jarros en el Puerto a quien sabéys.

${ }^{158}$ La carta acompaña al doc no 8 del Apéndice y, con él, fue presentada por Ramírez en el Consejo Real en 14 de Mayo.

159 Sic por darán. 
Vuestra Reverençia me dixo de aquel esclavillo de X hasta XIV guineo o loro por el mejor preçio, procura que se aya aý o en El Puerto e (escriví?) el preçio y con brevedad porque es bien hazer lo que prometístes e mayormente contra las personas no ayaras qué dezir salvo que nuestro Señor sea en su guarda.

De Sevilla a VII de abril.

A su mandado señores. Christóval Díaz (rúbrica) ${ }^{160}$.

[1526, abril, 19. Sevilla] ${ }^{161}$.

Cristóbal Díaz, escribano de los reinos, vecino de Cádiæ, pide al rey que anule la renuncia del oficio de escribanía del número que otorgó en beneficio de Ramírez por violenta e por forçosa y mande dar sobrecarta del titulo y carta de merced en su favor.

AGS, CRC, 87, 7-I, fols 1r.-2v.

$$
\text { (Crus) }
$$

Muy poderosos señores ${ }^{162}$

Christóval Díaz, escriuano de vuestra Magestad, vezino de Cádiz, respondiendo a la petiçión de Diego Ramírez de la Rúa, vezino otrosí de la dicha çibdad, la qual dio en la Cámara e vuestra Magestad la mandó remitir al su Consejo para que en él se hiziese justiçia, por la qual el dicho Diego Ramírez confiesa que él renunçió en mi favor vna escrivanía del número de la dicha çibdad, de la qual por virtud de la dicha renunçiaçión, vuestra Magestad me hizo merçed e que después él contradixo la dicha renunçiaçión e que yo renunçié la dicha merçed que vuestra Magestad me hizo e pide que vuestra Magestad le confirme el dicho ofiçio de escrivanía, según que más largamente en la dicha petiçión se contiene, cuyo tenor, avido aquí por repetido, digo que vuestra Alteza no deve mandar hazer cosa de lo pedido por el dicho Diego Ramírez por lo siguiente:

Lo primero porque el dicho Diego Ramírez no es parte para pedir lo que pide. Lo otro porque su pedimento no proçede ni a lugar de derecho. Lo otro porque la escritura de renunçiaçión que presenta no es pública ni $[. .$.$] tente ni tal a quien se deva dar fee e crédito ni la persona de quien viene$ sinada es la que en la suscriçión se nonbra. Lo otro porque pues que la dicha escriptura sea verdadera fue otorgada fuera de toda mi libertad, opreso, apremiado, ynduzido, atemorizado para la conçeder y otorgar porque hallará vuestra Magestad que el dicho Diego Ramírez me renunçió el dicho ofiçio e, por virtud de la dicha renunçia, vuestra Magestad me hizo merçed de él, segund que consta por el título presentado por el dicho Diego Ramírez, ya que yo lo despachava por me fatigar e maltratar el dicho Diego Ramírez y los cónplices que abaxo se declararán tovieron forma para que el dicho Diego Ramírez reclamase, como reclamó, de la dicha renunçiaçión ante el teniente de Cádiz, e por dañar la negoçiaçión declaró ante el dicho teniente que el dicho ofiçio avía sido vendido, el qual sin tener juridiçión para ello, syn çitarme, syn oyrme, syn orden de derecho, syn tela de juizio, pronunçió e declaró por perdido el dicho ofiçio y la cavsa porque lo hizo es porque el dicho teniente se ajuntó

${ }^{160}$ En el vuelto de la carta: A mys señores hermanos, Alonso de Medina e Diego Gonçález, escriuanos públicos, en Cádiz, de porte quatro maravedís.

${ }^{161}$ Fecha de presentación en el Consejo Real.

162 Al margen, bajo los destinatarios: Christóval Díaz, escriuano, vezino de Cádiz, contra Diego Ramírez de la Rúa, vezino de la dicha ciudad. En el ángulo superior derecho: que por fuerças e temores se la fizieron renunçiar. 
con Jayme de Luna, regidor de aquella çibdad, a quien él es muy parçial e el dicho regidor es muy amigo del dicho Diego Ramírez e se confederaron e prometieron e juraron que avnque yo troxese confirmaçión de la dicha escrivanía que no me resçibirían a ella //1v e poniendo su propósyto en efeto requirieron a todos los regidores de la dicha çibdad que no me reçibiesen al dicho ofiçio e el dicho teniente publicó que avnque yo llevase primera e segunda e terçera carta no me avía de reçibir al ofiçio e juró por la vida de vuestra sacra Magestad que hasta que vuestra Magestad con su boca la mandase no me avía de reçibir al dicho oficio, que fue cosa de muy gran desacato e que puso mucho escándalo en la dicha çibdad ver que el dicho teniente tan animosamente se mostrava de no obedeçer los mandamientos de los del vuestro muy alto Consejo ni los de vuestra Magestad e que pusiese en plática que no avía de obedeçer sino lo que vuestra Magestad le mandase en presençia. E, demás desto, el dicho Jayme de Luna cunpliendo la dicha confederaçión prometió e publicó que avía de gastar quanto tenía para que yo no fuese escriuano. Es asý que yo llevé la dicha provisión de vuestra Magestad e el dicho teniente la ora que supo que hera llegado dio mandamientos para prenderme so color de cosas muy livianas e que avían acaeçido muchos días avía e de que él me tenía dado en fiado y por tener yo logar de vsar de la dicha provisión retróxome a vna yglesia porque no me prendiesen, donde el dicho teniente e el dicho Jayme de Luna con muchas personas me enbió a dezir que tornarse a renunçiar el ofiçio en el mismo Diego Ramírez e que me libraría de lo que asý me oponían donde no que me prendería e pornía en la cárçel e allí me ternía para que no pudiese presentar la provisión e por aquella vía me haría e por otras mucho mal e daño. E que, asý mismo, prendería a mis hermanos porque no pudiesen venir a quexarse ni a librarme e que, avnque presentase la provisión, no me reçibirían antes suplicarían della e de otras tres que viniesen así que por los susodichos me fueron hechos e enbiados e publicados muchos temores e amenazas, así contra mí como contra mis hermanos, y tales que cayeran en qualquier constante varón. Demás desto los alguaziles andávanme esperando çerca de la yglesia para que si saliese me prendiesen e me pusiesen en parte donde no pudiese presentar la dicha provisión. Visto esto por mis hermanos con temor de la dicha justiçia e del dicho Jayme de Luna, que es persona que en aquella çibdad vale e puede mucho, hiziéronme salir de la yglesia a renpuxones e por fuerça e, contra mi voluntad, me llevaron a casa del dicho Jayme de Luna $/ / 2$ r. donde fue luego el dicho teniente para asistir e favoresçer la dicha fuerça e opresyón e para que no çesase el miedo antes autorizar la fuerça con su presençia e allí hordenaron e hizieron la dicha renunçiaçión e escriptura como quisyeron e por bien tovieron y el mismo alcalde ynterpuso su avtoridad, cosa jamás vista ni oýda en semejante escriptura y lo que peor es que puso por condiçión que me librarían de los cargos que se me oponían e ansí lo hizieron, que luego, sin más tela de juizio, me condenaron voluntariamente e luego alçaron la voluntad y no ovo más, de manera que donde ovo tanto recado para prenderme luego que se cunplió la voluntad del teniente se alivió la culpa e con esto claramente que la guarda e prisión que me fazían e querían hazer no hera por otra razón syno para que no toviese libertad de vsar de la dicha provisión. E, demás desto, siendo día hordinario de cabildo e Ayuntamiento, no lo quisieron hazer porque yo no toviese logar de presentar la dicha provisión hasta que me oviese hecho la dicha fuerça, de la qual antes e después de la dicha renunçiaçión yo reclamé muchas vezes ante muchas e diversas personas hize protestaçiones, aperçibimientos e luego que me vi en libertad me puse en camino para me quexar dello ante vuestra Magestad a los del vuestro muy alto Consejo e, por temor que le despachase la provisión por cámara, di petiçión ante el secretario Covos para que no se despachase e así se hizo. De manera que todo lo susodicho se hizo contra mi voluntad e todo lo que otorgué fue forçado, apremiado, conpulso, atemorizado e opreso e pues las renunçiaçiones que el onbre haze de su derecho an de ser libres e en ellas no a de aver premia e en esta renunçiaçión ovo tantas e muchas más que he dicho e para las hazer yntervino la justiçia que tiene muchas manos e grandes para hazer todo lo que quiere buscando diversos colores para lo traer a efeto. E, demás desto, los regidores de la dicha çibdad e los más del pueblo della dirán e así es la verdad que cunple más a vuestro serviçio que yo tenga el ofiçio que no 
el dicho Diego Ramírez porque soy más ábil e más sufiçiente y más de confianza que no él.

Por ende, a vuestra Alteza suplico que no dé lugar a que la dicha renunçiaçión pase declarándola por violenta e por forçosa e tal que no tiene vigor ni fuerça de renunçiaçión y que haziéndome justiçia / 2v. pues la justiçia de Cádiz está tan flaca para mi favor y tan rezia en favor de mi contrario que vuestra Magestad mande dar sobrecarta del dicho título y carta de merçed que tengo enbiando vna persona de confiança para que me haga dar la posesión del dicho ofiçio e que me admita al vso y exerçiçio de él y, esto hecho, yo estaré a derecho con el dicho Diego Ramírez e con otra qualquier persona en razón de la dicha escrivanía. Para lo qual vuestro real ofiçio ynploro e pido conplimiento de justiçia e las costas e ofrézcome a probar lo neçesario.

[1526, abril, 21. Sevilla] ${ }^{163}$

Diego Ramírez de la Rúa, vecino de Cádiə, pide al rey que se pase la renuncia del oficio de escribanía del número otorgada por Díaz en su favor y se le dé el titulo.

AGS, CRC, 87, 7-I, fol 3r.

(Crus)

Muy poderosos señores ${ }^{164}$.

Diego Ramírez de la Rúa, vezino de Cádiz, respondiendo a una petiçión presentada por Christóval Díaz e su thenor avido por resumido, digo que vuestra Magestad deve mandar pasar la renunçiaçión por él fecha e proveerme del ofiçio de escriuanía syn enbargo de lo que el dicho Christóval Díaz dize que no obsta porque no es dicho por parte ni en tienpo ni en forma e porque como él dize y confiesa esta escriuanía fue mía e yo la vsé mucho tienpo e sy le fize renunçiaçión della fue engañado y atraýdo para ello. Y luego revoqué la renunçiaçión y lo reclamé ante la justiçia de la dicha çibdad e sabyéndolo él syn fazer mynçión dello obrretyçiamente e subrretyciamente ganó de vuestra Magestad la provisyón de la dicha escriuanía e, después, visto e conosçido que no tenía razón ni justiçia, ovo por bien de me la tornar a renunçiar e renunçiar en manos de vuestra Magestad el derecho que a ella toviese para que yo fuese proveýdo della porque más fáçilmente yo la pudiese recobrar, lo qual fize de su voluntad y ante la justiçia y el escriuano ante quien pasó es su hermano. No ovo el miedo ni ynduzimiento ni fuerça que dize ni tal se deve presumir, todo lo dize y alega a fin de me ynpedir la provisyón y me fazer daño y asý lo ha dicho y publicado. No deve vuestra Magestad dar lugar a que por su dicho e oposyçión se dilate la provisyón pues este ofiçio es mío y lo fue e sy él algund derecho tuvo a él fue por mi renunçiaçión la qual yo revoqué y contradixe e pues él fizo renunçiaçión de qualquier derecho que toviese y ovo por bien que el ofiçio se tornase a mí no lo ha de ynpedir agora su contradiçión que sy esta avía de thener efeto de derecho tanbién la avía de thener la mía en la renunçiaçión que yo a él le fize y quitada la vna y la otra el ofiçio quedarýa mío por la primera provisyón que de él tuve y esto más es recobrar mi primer derecho que adquirýles de nuevo ni pedir nueva merçed e yo tengo mucha más habilidad para el ofiçio que no él porque lo he vsado mucho tienpo e él vernía de nuevo a aprender e al servicio de vuestra Magestad ni al bien de aquella çibdad no conviene que él sea escriuano porque ay allí otros dos hermanos suyos escriuanos públicos e serýa mucho ynconveniente que tres hermanos fuesen escriuanos e por otras cabsas de que vuestra Magestad puede ser ynformados.

${ }^{163}$ Fecha de presentación en el Consejo Real.

164 Al margen superior derecho: pide Ramírez que se pase.

Trocadero, no 31 (2019), ISSN 2445-267X, pp. 1-48 
Pydo e suplico a vuestra Magestad que, syn dar lugar a dilaçión, mande que la dicha renunçiaçión se pase e se me haga merçed del dicho ofiçio, mandándome dar nueva provisyón de él e que yo le pueda vsar por la primera, anulando e revocando la fecha al dicho Christóval Díaz e fazyéndome en todo conplimiento de justiçia, para lo qual su real ofiçio ynploro y las costas pydo y concluyo negando lo perjudiçial.

El liçençiado Herrera (rúbrica).

[1526, mayo, 14] ${ }^{165}$.

Diego Ramírez de la Rúa pide al rey que le mande afianzar de las costas, daños e intereses que a causa de Cristóbal Díazy por su culpa se incrementarán y, en su defecto, que le aprese.

AGS, CRC, 87, 7-I, fol 33r.

(Crus)

Muy poderosos señores

Diego Ramírez de la Rúa en este pleito que trato con Christóval Díaz digo que el dicho Christóval Díaz calupniosamente, sabiendo que no tiene justiçia, insiste en este dicho pleito solamente a fin de hazerme daño y asý lo a publicado y asý paresçe por esta carta misiva escripta de su letra e firmada de su mano e firma ${ }^{166}$. Y porque sobre la dicha cavsa yo he hecho e hago muchas costas y el dicho Christóval Díaz es viandante, pydo e suplico a vuestra Alteza le mande afiançar de las dichas costas e daños e intereses que a su cavsa e por su dolo e culpa se me recreçerán y en defeto della que sea preso. Sobre que pido justiçia e su real ofiçio inploro.

[1526, junio, 29. Granada] ${ }^{167}$

Diego Sánchez Bernal, Diego Ortiz de Cubas, Diego Sánchez de Cádiz, Simón Gentil, Diego Sánchez de Argumedo, Andrea Doria, Pedro Marrufo, Diego Sánchez Sanabria, Lázaro Estopiñán, Pedro Cabrón, Pedro de Estopiñán y otro, regidores gaditanos, piden al rey que confirme a Cristóbal Díaz. como escribano público del número de Cádir:

AGS, CRC, 87, 7-I, fol 43r.-v.

$$
\text { (Crus) }
$$

\section{Sacra Católica Cesárea Magestad}

Los regidores, caballeros de la muy noble çibdad de Cádiz, besamos los reales pies y manos de vuestra Magestad. E dezimos que a nuestra notiçia es venido que en vuestro muy alto Consejo se trata pleyto pendiente entre Christó[val Díaz, escriuano de vuestr]a Magestad, e Diego Ramírez de la Rúa sobre la escriuanía del número que el dicho Diego Ramírez le re[nunçió e] vuestra Magestad hizo merçed al dicho Christóval Díaz e en el dicho pleito se presentó vna petiçión de algunos vezinos desta [çibdad e o] tras personas, la qual con formas e maneras que el dicho Diego Ramírez tovo fizo firmar no ynfor[mando de l]o en la petiçión contenido a los que asý firmaron. E por la dicha petiçión diz

165 En el ángulo superior izquierdo: A XIIII de mayo de I V DXXVI.

166 Cfr. Apéndice doc no 5.

${ }^{167}$ Fecha de presentación en el Consejo Real. 
que se dize çiertas cosas y casos [...] dicho Christóval Díaz e Diego Gonçález e Alonso de Medina, escriuanos públicos, sus hermanos, e porque [...]mos tenido e tenemos e se tiene comúndmente en esta çibdad a los dichos Christóval Díaz e sus hermanos [...] personas honrradas e de mucha fidelidad e buena vida e fama e trato y conversaçión, ábiles [e sufiçiente]s e an hecho e fazen tales obras que vuestra Magestad es servido dellos en los dichos ofiçios en tal man[era que no ay] ynconveniente que el dicho Christóval Díaz sea escriuano desta çibdad porque es de la calidad ya dicha e [...]os quatro escriuanos del número en esta çibdad, suplicamos a vuestra Magestad, syn enbargo de lo en la dicha peti[çión contenido] e de lo demás que contra los dichos Christóval Díaz e sus hermanos se dixere, mande confirmar [...] el dicho Christóval Díaz siendo servido de le mandar fazer justiçia porque en ello reçibiremos merçed [...].

Diego Sánchez Bernal (rúbrica), Diego Ortiz de Cubas (rúbrica), Diego Sánchez de Cádiz (rúbrica), Simón Gentil (rúbrica), Diego Sánchez de Argumedo (rúbrica), Andrea Doria (rúbrica), Pedro Marrufo (rúbrica), Diego Sánchez Sanabria (rúbrica), Lázaro Estopiñán(rúbrica), Pedro Cabrón(rúbrica), Pedro de Estopiñán (rúbrica), [...] (rúbrica).

1526, septiembre, 6. Granada.

Cristóbal Díaz, escribano de los reinos, vecino de Cádir, se aparta del pleito sostenido con Diego Ramírez. de la Rúa sobre la escribanía del número de Cádiz que le renunció y suplica confirme en el oficio a Ramírez:

AGS, CRC, 763, 1, 45, sf.

$$
\text { (Cruz) })^{168}
$$

Muy poderosos señores.

Christóval Díaz, escriuano de vuestra Magestad, vezyno de la çibdad de Cádiz, digo que ya vuestra Magestad sabe como yo ove renunçiado en Diego Ramírez de la Rúa, escriuano público desta dicha çibdad, el escrivanýa pública que él antes tenýa y me avía primero renunçiado y después yo me opuse contra la dicha renunçiaçión por mí fecha. E sobre ello avemos traýdo pleito en el Consejo de vuestra Alteza y porque las partes estamos conçertados y el dicho ofiçio es del dicho Diego Ramírez e le perteneçe, yo me aparto del dicho pleito e suplico a vuestra Alteza mande confirmar el dicho ofiçio al dicho Diego Ramírez y darle título de él para que él lo vse e exerça como suyo, como de antes lo vsava, en lo qual señalada merçed reçibiré.

Y, de como lo pido e suplico a vuestra Alteza, lo syné con mi signo e firmé de mi nonbre.

Fecho en Granada, a seys días de setienbre de mill e quinientos e veynte e seys años.

(Signo) En testimonio de verdad, Christóval Díaz, escriuano de vuestra Magestad (rúbrica).

\section{Anexo}

\subsection{Preguntas de la probanza de Cristóbal Díaz}

1. Primeramente si conosçen a mí, el dicho Christóual Díaz, e sy conosçen al dicho Diego Ramírez de la Rúa e sy conosçen al liçençiado Diego Téllez, theniente de corregidor de Cádiz, e a Jayme de Luna, reçeptor della.

${ }^{168}$ En el vuelto de la súplica: Christóbal Díaz. Fiat. Póngase en el proçeso. En Granada, a X de setienbre de DXXVI. 
2. Yten si saben que el dicho Diego Ramírez es muy amigo e allegado del dicho Jayme de Luna.

3. Yten sy saben que el dicho theniente de corregidor es muy parçial al dicho Jayme de Luna e declaren los testigos en qué casos e cosas an visto al dicho theniente ser parçial del dicho Jayme de Luna e qué cosas le han visto hazer por qué creen e saben la dicha parçialidad e sy saben que, ansý mismo, el dicho theniente es muy amigo del dicho Diego Ramírez.

4. Yten sy saben que el dicho Jayme de Luna es tan rico e tan poderoso e tan sabio e mañoso que en la dicha çibdad de Cádiz no se haze syno lo que él quiere e por do él lo guía.

5. Yten sy saben, etçétera, que el dicho theniente y el dicho Jayme de Luna y el dicho Diego Ramírez se confederaron e prometieron e juraron que, avnque yo llevase provisión de su Magestad de la dicha escriuanía sobre que litigamos por virtud de la renunçiaçión que el dicho Diego Ramírez me hizo, no me resçibirían a ella.

6. Yten sy saben, etçétera, que pronunçiada la dicha confederaçión e propósito en efeto requirieron e rogaron a todos los regidores de la dicha çibdad e a cada vno dellos en particular que avnque yo traxese la dicha provisión no me resçibiesen al dicho ofiçio e sobre ello se hizieron muchos ruegos e muchas ofertas e otras palabras para ynduzillos e persuadillos e atraellos a ello.

7. Yten sy saben que el dicho theniente, pública e secretamente, dixo e publicó que avnque yo llevase //v. primera e segunda e terçera carta de su Magestad no me avía de resçibir al ofiçio. E juró por la bida del enperador, nuestro señor, que hasta que su Magestad con su boca lo mandase en presençia no me avía de resçibir al dicho ofiçio.

8. Yten sy saben, etçétera, que el dicho Jayme de Luna, cunpliendo la dicha confederaçión, prometió e publicó que avía de gastar quanto tenía para que yo no fuese resçebido al dicho ofiçio.

9. Yten sy saben, etçétera, que luego que yo llevé la dicha provisión, en sabiéndolo el dicho theniente que yo hera llegado, dio mandamientos para prenderme por cabsas libianas e de tienpo pasado e sin pedimiento de parte e sin querer a los fiadores que yo tenía dados de presentarme en la cárçel cada vez que él lo mandase.

10. Yten sy saben que como yo llegué e supe la voluntad del dicho theniente porque de hecho no me prendiese e tomase el título e para tener livertad de tornar a suplicar a su Magestad que me diese hesecutor de la dicha merçed que me pusiese en la posesión del dicho ofiçio yo me retruxe a la yglesia de la dicha çibdad para que dende allí pudiese negoçiar mis negoçios como he dicho.

11. Yten sy saben, etçétera, que, estando yo en la dicha yglesia, el dicho theniente y el dicho Jayme de Luna me enviaron a dezir junta e apartadamente con muchas e diversas personas y en diversas bezes e tienpos que tornase a renunçiar el dicho ofiçio en el dicho Diego Ramírez e que me libraría de lo que ansý me oponían donde no que me prenderían e pornía en la cárçel donde //r. no toviese lugar de vsar de la dicha provisión e por aquella vía e por otras me haría mucho mal e daño.

12. Yten sy saben, etçétera, que las mismas amenazas e otras muchas enviaron e fizieron a mis hermanos e publicaron que los avían de prender para que no pudiesen venir a quexarse ni a librarme de la dicha prisión e avn prendieron al vno dellos que se llama Alonso de Medina.

13. Yten sy saben, etçétera, que Allende desto publicaron muchos temores e amenazas, ansý contra mí como contra los dichos mis hermanos, e tantas extorsiones que a qualquier varón constante pudieran traer e traxieran justo temor e miedo porque el 
dicho theniente thenía la vara de justiçia y el dicho Jayme de Luna, como dicho es, es tan poderoso en aquella çibdad e avn suele poner sus amenazas en hexecuçión que es razón que qualquier le tema.

14. Yten sy saben, etçétera, que demás de las dichas amenazas, los alguaziles de la dicha çibdad, por mandado del dicho theniente, me esperavan y çercavan en la dicha yglesia para sy saliese prenderme e ponerme en parte donde no pudiese presentar la dicha provisión.

15. Yten sy saben, etçétera, que conpulsos e apremiados e forçados de los dichos themores e amenazas e obpresiones y extorsiones que los dichos thenientes e Jayme de Luna publicavan y enviavan, los dichos mis hermanos, con temor de la dicha justiçia, me hizieron salir / v de la yglesia a renpuxones e por fuerça e contra mi voluntad y me llevaron a casa del dicho Jayme de Luna donde, a la ora, fue el dicho theniente para asystir e faboresçer la dicha fuerça e obpresión e para que çesase el miedo con sus presençias e allí hordenaron e hizieron la dicha renunçiaçión y escriptura como quisieron e por bien tovieron syn que yo hablase palabra, chica ni grande, más de quanto dixe al dicho Jayme de Luna por qué me avía sido tan contrario en este negoçio y en mis meneos e senblante mostrava e mostré que forçado e contra mi voluntad fazía la dicha renunçiaçión e syn que fuese resçibido al dicho ofiçio ni oviese presentado la dicha provisyón.

16. Yten sy saben, etçétera, que puso por condiçión que sy yo fiziese la dicha renunçiaçión me libraría de los cargos que me oponían e asý se hizo. E syn tela de juyzio e sin otra horden de derecho me sentençió el dicho theniente por su voluntad e la alçó luego.

17. Yten sy saben, etçétera, que del día que yo llegué a la dicha çibdad o otro día siguiente por la mañana, que fue el viernes de la semana de Ramos próxima pasada, hera día hordinario de cabildo y el dicho theniente e Jayme de Luna no lo quisieron fazer porque yo no tuviese lugar de presentar la dicha provisión hasta que me oviesen fecho la dicha fuerça.

18. Yten sy saben, etçétera, que antes que yo fuese a hazer la dicha renunçiaçión hize una reclamación //r. de la dicha fuerça ante Diego Sánchez, escriuano público de la dicha çibdad, e los susodichos tuvieron forma para que no pasase en nota del dicho escriuano.

19. Yten sy saben, etçétera, que antes que hiziese la dicha renunçiaçión e después ante muchas e diversas personas reclamé e me quexé de la dicha fuerça que se me avía fecho.

20. Yten sy saben, etçétera, que luego que me avían livertado vine a la villa de Puerto Real e ante el juez hordinario della reclamé e pedý que se tomase vna ynformaçión en que demostrava mi ánimo y el agravio e quexa que tenía de la dicha fuerça.

21 Yten sy saben que yo, el dicho Christóval Díaz, soy persona ábil e sufiçiente para [vsar el dich]o ofiçio más que el dicho Diego Ramírez e de más y mejor confiança e crédito que [él], soy onbre de buena fama, trato e conversaçión e de mucha linpieza y que conbiene más a serviçio de su Magestad e al byen de la dicha çibdad de Cádiz que tenga yo el dicho ofiçio que no el dicho Diego Ramírez. Digan los testigos las cabsas, cómo e por qué lo saben.

22. Yten sy saben, etçétera, que Diego Gonçález e Alonso de Medina, mis hermanos, escrivanos del número de la dicha çibdad, son personas muy honradas, ábiles e linpios en sus ofiçios, no ynteresados, tratan bien los negoçiantes, despáchanlos presto en qualquier [...] e tienpo, entienden en sus ofiçios, son bien quistos en la dicha çibdad.

23. Yten sy saben, etçétera, que avnque yo tenga el dicho ofiçio de escriuano en la dicha 
çibdad concurriendo en //v. mí las calidades que he dicho no es ynconbeniente ser tres hermanos escrivanos del número porque cada ofiçio es distinto e apartado de por sý e ay otros quatro escriuanos del número en la dicha çibdad e, demás desto, en muchas çibdades e villas destos reynos ay dos e tres hermanos regidores e vn padre y en otra parte escriuanos. Digan lo que saben.

24. Yten sy saben, etçétera, que vna petiçión que en el proçeso está presentada que dize e suena ser otorgada por algunos vezinos de la dicha çibdad e dize estas palabras siguientes:

Los vezinos e moradores de la çibdad de Cádiz con vmillde reverençia besamos las reales manos de vuestra Magestad e dezimos que a venido a nuestra notiçia que vuestra Magestad a dado a Christóval Díaz la escrivanía pública del número que [vsava] en la dicha çibdad Diego Ramírez de la Rúa, escriuano público, por renunçiaçión que el dicho Diego Ramírez hizo, el qual dicho Diego Ramírez después reclamó e contradixo la dicha renunçiaçión porque la hizo con henojo e syn deliberaçión por dineros que le dieron. $\mathrm{E}$ ansý por consiguiente es en mucho daño e perjuizio de la república de la dicha çibdad e vezinos e moradores della por ser, como es, el dicho Christóval Díaz, de casta de christianos nuevos, persona sospechosa, tyene otros dos hermanos escriuanos que son Alonso de Medina e Diego González e, sy agora el dicho Christóval Díaz oviese de ser escriuano e lo tal pasase, está muy conosçido el daño que dello se sigue, por todo lo qual e porque el dicho Diego Ramírez de la Rúa es persona de mucha abilidad e sufiçiençia e christiano viejo e sienpre ha dado buena cuenta de sý e del dicho ofiçio e con quien toda la república tiene mucho contentamiento, humilldemente suplicamos que, //r. pues el dicho Diego Ramírez reclamó e contradixo la dicha renunçiaçión que hizo en tanto daño de su honrra e muger e hijos, los quales, ansý mismo, lo han contradicho, que vuestra Magestad lo reboque todo e dexe e mande dexar al dicho Diego Ramírez en el dicho ofiçio porque todo el pueblo lo queremos e lo pedimos e, sy algunos dineros ha resçibido, él está presto de los bolver e nosotros nos ofresçemos a los bolver, tanto que quede por escriuano, como agora lo es, en lo qual señalada merçed resçibiremos.

Lope de Portillo [...] e Fernán Díaz, Juan Díaz, Pedro de Medina, Luis Hernández, maestre, e Alonso de Fuentes, Blas de Frías, Rodrigo de Goyán, Pedro de Escobar, Christóval Rafael, Christóval Coronado, Gaspar de Frías, Antón Núñez, Juan [...], Juan Batista Franco, testigo, el doctor Alcab[dete], G[aspar de] Olmedo, Bartolomé de Treviño, Ambrosio de Casana, Françisco de Varea, Gregorio Perrachín, Juan de Mayorga, Juan de Gatica, Pero Martín de Palma, Polo Çenturión, Fernando de Argumedo, Roberto de Dyque, Juan de Sevilla, Pero Martín Pocasangre, Bartolomé Sofía, Alonso Garçía, clérigo, Jayme Castelo Elduque, Françisco Savli, Christóval Camacho, Jayme Fijayme, Christóval Sánchez, Lope Rodríguez, Pedro de Espinosa, Fernán Garçía de Truxillo, Juan Xinete, Pedro de Luna, menor, Juan Bernal, boticario, Antón Martín Parrado, Gonzalo Díaz, çirujano, Bartolomé Capilla, Antón Thomas, Miguel Mora, menor, Antón Galíndez, Diego Ortiz, Antón Galíndez, Pedro de Valladolid, Diego Ramírez, procurador e [el theso]rero de Cádiz.

Los más de los susodichos de suso declarados son criados, apaniaguados e familiares del dicho Jayme de Luna e los otros demás no supieron lo que //v. fyrmavan ni les fue dicho ni declarado e sy lo supieran o les fuera declarado no firmaran ni otorgaran la dicha petiçión ni cosa della. Yten sy saben que lo susodicho es pública boz e fama ${ }^{169}$.

${ }^{169}$ La carta original, copiada en la pregunta del interrogatorio, aparece también en AGS, CRC, 87, 7-I, fols 48r.49 v., y fue presentada al Consejo Real en 6 de julio. 


\section{(Preguntas añadidas:)}

25. Yten sy saben que el dicho Diego Ramírez sirve e a servido al dicho Jayme de Luna como si fuese su criado e ante él faze sus cosas el dicho Jayme de Luna e dende que el dicho Jayme de Luna enpeçó a faboresçerle sienpre el dicho Diego Ramírez fue e vino diversas vezes a casa del dicho Jayme de Luna como su moço e a darle cuenta de todas las cosas para que el dicho Jayme de Luna, por todas vías, le faboresçiese, forçando al dicho Christóval Díaz e faziendo muchas extorsiones al dicho Christóval Díaz e sus hermanos. Digan lo que saben.

26. Yten sy saben (que?) el día que se esperava benir el dicho Christóval Díaz de la Corte de su Magestad con la provisión susodicha del dicho ofiçio de escryvanía se juntavan e juntaron los dichos alcallde e Jayme de Luna e Diego Ramírez y el corregidor de la dicha çibdad para dar en las extorsiones e obpresiones que avían de fazer al dicho Christóval Díaz para que no oviese hefecto su provisión e contra sus hermanos por distrayllos ynjusta e yndevidamente para hefeto que forçadamente el dicho Christóval Díaz se desistiese del dicho ofiçio //r.

27. Yten sy saben que en la dicha çibdad de Cádiz se tiene públicamente por público y aberiguado e çierto que el dicho Christóval Díaz tornó a renunçiar al dicho Diego Ramírez el dicho ofiçio sin presentar en el cabildo de la dicha çibdad la merçed por fuerça e contra su voluntad por las fuerças e obpresyones e temores que le hizieron el dicho Jayme de Luna y el dicho alcalde, diziendo a muchos amigos e conosçedores del dicho Christóval Díaz e sus hermanos que, si el dicho Christóval Díaz no se dexava dellos no lo renunçiava en el dicho Diego Ramírez, que los avía de destruyr a todos tres e hazelles males e daños. Por manera que se tiene por aberiguado que, si no fuera por la dicha fuerça, que nunca el dicho Christóval Díaz renunçiara el dicho ofiçio e que fuera resçibido por los regidores de la dicha çibdad eçebto por el dicho alcalde y el dicho Jayme de Luna, los quales se hizieron en este caso partes formadas por el dicho Diego Ramírez e por le faboresçer e ansý lo dizen todos en la dicha çibdad públicamente e se tyene por aberiguado.

28. Yten sy saben, etçétera, que algunas personas, luego que el dicho Christóual Díaz fue benido con la dicha provisión de merçed a la dicha çibdad de la Corte de su Magestad retraýdo en la dicha yglesia, fueron a hablar a Jayme de Luna e al dicho alcalde e a rogarles que no fiziesen tanto mal como fazían al dicho Christóual Díaz / /v e a sus hermanos ni los molestasen ni obpremiesen como hazían e que les dexasen vsar de su provisión e seguir su justiçia e respondieron que en ninguna manera avía de aver el dicho ofiçio el dicho Christóual Díaz e que ellos avían de poner todas sus fuerças porque no saliese el dicho Christóual Díaz con el dicho ofiçio y, en fin, lo que más se publicava con ellos por las dichas personas fue que a los dos hermanos, mientras hablavan con el dicho Christóual Díaz sobre que renunçiase el dicho ofiçio, no los prenderían e que el dicho Christóual Díaz se guardase que, sy salía de la yglesia, lo avían de prender los alguaziles, que tenían mandamiento para ello tal por hefeto de fuerça, al dicho Christóual Díaz e porque por fuerça e contra su voluntad se dexase del dicho ofiçio e dando a entender que, sy no lo fazían, avían de hazer muchos males e daños a él e a sus hermanos. E ansý lo tienen por aberiguado los testigos, según lo que conosçieron e oyeron al dicho alcalde e al dicho Jayme de Luna, porque el dicho alcalde no hazía ni quería hazer más de lo que quería el dicho Jayme de Luna. Digan lo que saben. 


\section{(Preguntas añadidas):}

29. Yten sy saben, etçétera, que el dicho Diego Ramírez es persona que a tenido e tiene por costunbre de ser, como es público, tahúr que juega muchas quantidades de dineros con muchas personas e dexava de vsar e residir en el dicho ofiçio de escrivanía e se yba a jugar e las partes que ante él tenían sus negoçios lo pasavan mal no lo pudiendo fallar, demás dello suele e acostunbra llevar derechos demasiados y hexçesivos, e, asý mismo, es persona que deve muchas quantidades de maravedíes en esta çibdad a diversas personas, a sido preso en la cárçel pública por las dichas debdas e después por ellas retraýdo a la yglesia. Digan lo que saben.

30. Yten sy saben, etçétera, que esta çibdad de Cádiz está en ysla çercada de mar e no pueden salir della por tierra syno por agua e sy saben que dende el biernes de la semana de Ramos, próxima pasada, hasta la Pascua de Resurreçión de nuestro Redentor syguiente venidera deste presente año todo el dicho tienpo ovo en esta çibdad muy rezios tienpos de levante e tormenta en tal manera que no pudieron pasar ni pasaron los pasajes ni barcos e sy alguno pasó fue con muy gran peligro en tal manera que la gente que quería salir desta çibdad estava y estuvo detenida en esta çibdad que no podía salir della el dicho tienpo e ansý es público e notorio.

31. Yten sy saben que todo el dicho tienpo el dicho Christóual Díaz estuvo detenido en esta çibdad e avnque procurava de salir desta çibdad no podía ni pudo a cabsa de los dichos tienpos hasta tanto que fue a la dicha villa de Puerto Real170.

\subsection{Preguntas de las probanzas de Diego Ramírez de la Rúa}

1. Primeramente sean preguntados los dichos testigos sy conoçen al dicho Diego Ramírez, escriuano público, e sy conoçen al dicho Christóval Díaz e sy saben e se acuerdan de vn día del mes de março deste presente año que se contaron veynte e quatro días del dicho mes que fue býspera de Ramos.

2. Yten sy saben que a cabsa que su muger del dicho Diego Ramírez e su suegro e otras personas avían sentido mucho e reçebido pena porque el dicho Diego Ramírez avía renunçiado el ofiçio de escriuano del número de la dicha çibdad de Cádiz en fabor del dicho Christóval Díaz e por vertud de la dicha renunçiaçión dezían que su Magestad avía fecho título al dicho //v. Christóval del dicho ofiçio luego que el dicho Christóval Díaz bolbyó de la Corte a la dicha çibdad de Cádiz el liçençiado Estopiñán, predicador, de parte del dicho Diego Ramírez e de su muger e de su suegro, rogaron al dicho Christóval Díaz e a sus hermanos que bolbyesen a renunçiar el dicho ofiçio en el dicho Diego Ramírez porque no fuese cabsa de estar sienpre mal casado con la dicha su muger. Digan los testigos lo que saben.

3. Yten sy saben que el dicho Christóval Díaz e sus hermanos mostraron voluntad de bolver a hazer la dicha renunçiaçión pagándoles las costas e gastos que avían fecho e que el dicho liçençiado Estopyñán les dixo que hera justo que se les pagasen e con esto ellos ovyeron por byen de bolver a hazer la dicha renunçiaçión e asý lo dieron por respuesta sus hermanos, las quales dichas costas fueron tasadas e moderadas por el dicho liçençiado Estopiñán e por Jayme de Luna, regidor, en çinqüenta ducados.

4. Yten sy saben que al tienpo que el dicho Christóval Díaz e sus hermanos vynieron a la posada del dicho Jayme de Luna, regidor, a hazer la dicha renunçiaçión que sería a ora de býsperas se bynieron solos, todos tres hermanos, syn que vyniesen con ellos persona alguna, lo qual saben los testigos porque los vyeron venir e que no fueron conpulsos ni

${ }_{170}$ AGS, CRC, 87, 7-III, sf. 
apremiados //r. para venir a la dicha casa antes pudieran dexar de venir sy quisyeran.

5. Yten sy saben que, estando en la dicha posada del dicho Jayme de Luna, regidor, el dicho Christóval Díaz dixo, en presençia de todas las personas que ende estavan, que él hera contento de bolver a renunçiar el dicho ofiçio en el dicho Diego Ramírez e asý, en presençia de los dichos testigos, hizo la dicha renunçiaçión por ante Diego Gonçález, su hermano, e que antes e al tienpo que lo susodicho pasase no se le dixo palabra por el dicho Jayme de Luna ni por otras personas algunas que ende estovyese que fuese para hazerle amenaza ni ponerle temor porque, sy tal fuera, los testigos lo vyeran e supieran porque estovyeron presentes, antes fue con mucho plazer e voluntad de todos e hizieron colaçión e que el dicho Diego Ramírez les dio e pagó los dichos çinqüenta ducados de costas e yntereses de más del prinçipal que fueron otros quinientos e setenta e çinco ducados.

6. Yten si saben que para que el dicho abto de renunçiaçión tuvyese más abtoridad, de común voluntad de todos, acordaron de enbiar a llamar al alcalde mayor para que pasase todo ante él e sy saben que antes e después de llegado el dicho alcalde mayor el dicho Christóval Díaz e sus hermanos mostraron voluntad de hazer la dicha renunçiaçión. //v

7. Yten sy saben que, después de fecha la dicha renunçiaçión, algunos días el dicho Christóval Díaz estovo en la dicha çibdad de Cádiz e, platicando con él algunas personas sobre el dicho ofiçio, le dezía e respondía que lo avýa renunçiado en favor del dicho Diego Ramírez mostrando contentamiento de la dicha renunçiaçión e digan los testigos lo que saben.

8. Yten sy saben que después que este pleyto se sygue el dicho Christóval Díaz a dicho e publicado que bien conoçe que no tiene justiçia más que quiere seguir el dicho pleyto por hazer daño al dicho Diego Ramírez e por hazerle gastar.

9. Yten sy saben que sy la justiçia de la dicha çibdad de Cádiz avía dado mandamientos para prender al dicho Christóval Díaz e los alguaziles lo querían prender hera porque dio vna cuchillada a Gaspar de Haya por palabras que ovyeron porque lo metió el dicho Christóval Díaz en vn perque que hizo por $<$ el $>$ qual delyto estava apregonado.

10. Yten sy saben que por todo el tienpo que el dicho Diego Ramírez a tenido el dicho ofiçio de escrivanía, que puede aver quinze años, la a vsado muy bien e fiel e dilygentemente e que tiene mucha abylydad para el vso e exerçiçio del dicho ofiçio, es byen quisto de todos los escriuanos //r. de la çibdad e que sería e es muy provechoso al byen público de la dicha çibdad e vezinos della que el dicho Diego Ramírez vse e se tenga el dicho su ofiçio antes que el dicho Christóval Díaz e asý es más seruiçio de su Magestad.

11. Yten sy saben que el dicho Christóval Díaz tiene otros dos hermanos escriuanos públicos del número de la dicha çibdad que son Alonso de Medina e Diego Gonçález.

12. Yten sy saben que el dicho Christóval Díaz es de casta de christianos nuevos porque su padre fue judýo e sy saben que es persona sospechosa porque oy en día tiene primos e parientes e personas de su casta que se pasaron en alyende seyendo christianos e se tornaron de christianos judíos e asý como judíos byben en Fez e en Çalé e en otras partes de alyende, en espeçial Christóval Díaz, hijo de Beatriz Núñez, que agora se llama, después que se tornó judío, Samuel de Sornaga e su muger e hijos, e la Mirona e sus hijos, e Méndez e su muger e hijos e Antón Martín, sastre, e su muger e hijos, e çiertos hijos de Tomás Moreno.

13. Yten sy saben que todo lo susodicho a seýdo e es pública boz e fama e séanles fechas las otras preguntas al caso perteneçientes. Diego Ramírez de la Rúa, escriuano público e de sus Magestades ${ }^{171}$.

171 AGS, CRC, 87, 7- IV, sf. 